\title{
Fiscal Federalism and the Deductibility of State and Local Taxes in a Federal Income Tax
}

\section{Citation}

Louis Kaplow, Fiscal Federalism and the Deductibility of State and Local Taxes in a Federal Income Tax, 82 Va. L. Rev. 413 (1996).

\section{Published Version}

doi: $10.2307 / 1073520$

\section{Permanent link}

http://nrs.harvard.edu/urn-3:HUL.InstRepos:10611786

\section{Terms of Use}

This article was downloaded from Harvard University's DASH repository, and is made available under the terms and conditions applicable to Other Posted Material, as set forth at http:// nrs.harvard.edu/urn-3:HUL.InstRepos:dash.current.terms-of-use\#LAA

\section{Share Your Story}

The Harvard community has made this article openly available.

Please share how this access benefits you. Submit a story.

\section{Accessibility}




\section{HEINONLINE}

Citation: 82 Va. L. Rev. 4131996

Content downloaded/printed from HeinOnline (http://heinonline.org)

Mon Feb 22 11:19:32 2010

-- Your use of this HeinOnline PDF indicates your acceptance of HeinOnline's Terms and Conditions of the license agreement available at http://heinonline.org/HOL/License

-- The search text of this PDF is generated from uncorrected OCR text.

-- To obtain permission to use this article beyond the scope of your HeinOnline license, please use:

https://www.copyright.com/ccc/basicSearch.do?

\&operation $=$ go\&search Type $=0$

\&lastSearch $=$ simple\&all=on\&titleOrStdNo=0042-6601 


\section{VIRGINIA LAW REVIEW}

\begin{tabular}{lll}
\hline \hline VOLUME 82 & APRIL 1996 & NUMBER 3 \\
\hline
\end{tabular}

ARTICLE

\section{FISCAL FEDERALISM AND THE DEDUCTIBILITY OF STATE AND LOCAL TAXES UNDER THE FEDERAL INCOME TAX}

\section{Louis Kaplow*}

Whether state and local taxes are deductible is believed to have important effects on revenue, tax equity, and the operation of state and local governments. This Article's analysis of deductibility draws on previous work that addresses the fiscal activity of state and local governments in order to examine the incidence of both taxes and the benefits they finance. The desirability of deductibility is assessed not only by reference to whether it is required by a conceptually pure income tax but also in terms of how it serves the underlying objectives of the income tax. The results of this investigation contradict many of the arguments offered by advocates and opponents of deductibility.

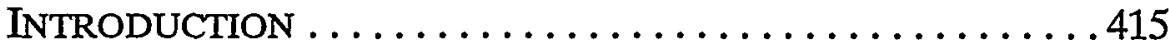

I. BENCHMARK CASES AND ABILITY TO PAY ........420

A. Taxes Equal to Benefits within the Jurisdiction . . . 421

B. Taxes Unrelated to Benefits within the Jurisdiction . 423

1. Basic Analysis .................423

- Professor, Harvard Law School and Research Associate, National Bureau of Economic Research. I am grateful for comments from William Andrews, David Bradford, Howell Jackson, Christine Jolls, Daniel Rubinfeld, Daniel Shaviro, and workshop participants. I am also grateful for research assistance from David Elsberg and George Wang and for support from the John M. Olin Center for Law, Economics, and Business at Harvard Law School. 
2. Intermediate Cases . . . . . . . . . . . .426

3. Fiscal Equalization ................. . . . . . . . . . . . . . . .

4. Demographic Redistribution ... . . . . . . 429

5. Summary ....................4430

C. Ability to Pay and Economic Well-Being . . . . . . . . 430

1. Competing Bases for Valuation . . . . . . . . . 431

2. Comparison to Cost-of-Living Adjustments . . . . 435

a. Simple Cost-of-Living Adjustments ......445

b. Application to State and Local Taxes . . . . . 436

II. INCIDENCE: BENEFIT VIEW VERSUS NEW VIEW $\ldots \ldots 441$

A. Benefit View . . . . . . . . . . . . . . . . . . .442

1. The Simple Benefit View . . . . . . . . . . . .442

2. Perfect Capitalization ...............445

B. New View . . . . . . . . . . . . . . . . . . . .448

1. Explanation . . . . . . . . . . . . . 448

2. Appropriate Treatment . . . . . . . . . . . 449

a. Landlords . . . . . . . . . . . . . . . . . . . . . . . . . . . . . . . . . . . . . . . . .

b. Renters ..................4450

c. Owner-Occupiers . . . . . . . . . . . . 452

3. Relationship between Taxes and Benefits under the

New View . . . . . . . . . . . . . . . . . 454

4. Land versus Structures . . . . . . . . . . . 456

5. Evidence on the New View . . . . . . . . . 457

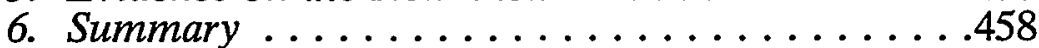

C. Sales and Income Taxes . . . . . . . . . . . . . .458

III. BUSINESS TAXES AND TAX INCIDENCE $\ldots \ldots \ldots \ldots \ldots 461$

A. The Incidence of Business Taxes . . . . . . . . . . 461

B. Types of Taxes . . . . . . . . . . . . . . . 464

1. Sales Taxes . . . . . . . . . . . . . . . . . . .464

2. Income and Wage Taxes ............. 466

3. The Incidence of Business Taxes Revisited . . . . 467

C. Tax Exporting ...................4469

IV. REDISTRIBUTION . . . . . . . . . . . . . . . 471

A. Limits on Local Redistribution . . . . . . . . 472

B. General Redistributive Motives . . . . . . . . . . 474

C. Redistribution as a Local Public Good . . . . . . . 478

D. Coercive Redistribution . . . . . . . . . . . . . . . 479

V. INTERJURISDICTIONAL SPILLOVERS $\ldots \ldots \ldots \ldots \ldots 480$

A. Sources..........................480

B. Relevance to Deductibility . . . . . . . . . . 481

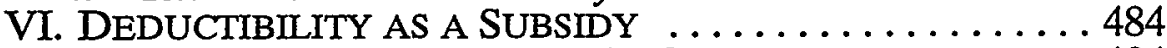

A. Comparison to Direct Subsidies . . . . . . . . . . . 484 
B. Effect of Deductibility on State and Local Spending ......................486

C. Efficiency of Decisions about State and Local Goods and Services ...........................489 VII. CONCLUSION . . . . . . . . . . . . . . . . . . . . . 490

\section{INTRODUCTION}

GEDERAL income tax ${ }^{1}$ deductibility of state and local taxes 1 paid by individuals ${ }^{2}$ purportedly generated a revenue loss of forty billion dollars in fiscal year 1995.3 Of the primary state and local revenue sources, income and property taxes are deductible (by itemizers ${ }^{4}$ ) whereas sales taxes are not. ${ }^{5}$ Whether

1 Analysis for a consumption (or cash flow) tax would be similar, although differences in the treatment of housing purchases may be relevant to treatment of the property tax. See, e.g., David F. Bradford \& the U.S. Treasury Tax Policy Staff, Blueprints for Basic Tax Reform 105 (2d ed. 1984).

${ }^{2}$ I.R.C. $§ 164$ (1994). Businesses deduct state and local taxes as an ordinary business expense. I.R.C. $\S 162$. Unless otherwise indicated, this Article refers only to personal deductions for state and local taxes. Part III addresses some aspects of business deductions. Foreign taxes are also deductible, I.R.C. $\$ 164(\mathrm{a})$, and may be subject to a tax credit, I.R.C. $\$ 901$; foreign taxes raise problems of intergovernmental relations (analogous to the issue of how one state's taxes should be treated by another state) rather than the vertical problems (national government versus state or local) that are addressed here.

${ }^{3}$ See Office of Management \& Budget, Executive Office of the President of the U.S., Budget of the U.S. Government: Analytical Perspectives, Fiscal Year 1995, 56 (Table 6-1) (1994). To the extent deductibility affects the types of state and local taxes employed, however, eliminating deductibility would raise less revenue than such static budget estimates indicate. See George R. Zodrow, Eliminating State and Local Tax Deductibility: A General Equilibrium Model of Revenue Effects, in Fiscal Federalism: Quantitative Studies 177 (Harvey S. Rosen ed., 1988) (stating that substitution among taxes used would result in signiflcantly less revenue than Treasury estimates); Martin S. Feldstein \& Gilbert E. Metcalf, The Effect of Federal Tax Deductibility on State and Local Taxes and Spending, 95 J. Pol. Econ. 710 (1987) (stating that due to possible shift in types of taxes used, eliminating deductibility may raise little or no revenue). But see Douglas Holtz-Eakin \& Harvey S. Rosen, Tax Deductibility and Municipal Budget Structure, in Fiscal Federalism, supra, at 107 (stating that removing deductibility would cause significant fall in collections of deductible taxes and local spending and stating that there is no significant evidence of tax substitution mitigating resulting increase in federal tax revenue); Lawrence B. Lindsey, Federal Deductibility of State and Local Taxes: A Test of Public Choice by Representative Government, in Fiscal Federalism, supra, at 137 (stating that state and local spending significantly affected by deductibility). For further discussion and evidence, see infra note 206.

${ }^{4}$ See I.R.C. $\$ \$ 62,63$ (d) (1994). The analysis focuses on whether, in principle, there should be a deduction. Whether the deduction should be available only to itemizers is an administrative concern that will not be considered here. See Louis Kaplow, The Standard Deduction and Floors in the Income Tax, 50 Tax L. Rev. 1 
state and local taxes are deductible is believed to have important effects on revenue, tax equity, and the operation of state and local governments. Untangling and assessing these effects liave proved difficult. As a result, the desirability of the deduction remains controversial. Many tax reform proposals would eliminate the deduction. ${ }^{6}$

This Article provides a framework to assess whetler individuals should be allowed to deduct state and local taxes in determining their taxable imcome under the federal income tax. The Article focuses on what rules provide the most accurate income measurement, and it also discusses efficiency considerations. ${ }^{7}$ The analysis differs from most prior work ${ }^{8}$ in three ways. First,

(1994). When the deduction is limited to itemizers, its distributive, subsidy, and incentive effects will differ, as discussed infra notes 196 and 199 and in Section VI.B.

${ }^{5}$ I.R.C. § 164(a) (1994). Prior to the 1986 tax reform, sales taxes were deductible.

${ }^{6}$ For example, the important Treasury Department study Blueprints for Basic Tax Reform, released in 1977, recommended retaining the deductibility of state and local income taxes but not of sales or property taxes. Bradford \& the U.S. Treasury Tax Policy Staff, supra note 1, at 83-86. (For discussion of why sales and income taxes were to be treated differently, see infra note 147.) Subsequent Treasury Department proposals called for the elimination of the personal deduction for all state and local taxes. See 1 U.S. Dept. of Treasury, Tax Reform for Fairness, Simplicity, and Economic Growth, at 78-81 (1984) [hereinafter Treasury I], 2 id. at 62-68; The President's Tax Proposals to the Congress for Fairness, Growth, and Simplicity $62-69$ (1985) [hereinafter Treasury II]; see also Bruce Bartlett, The Case for Eliminating Deductibility of State and Local Taxes, 28 Tax Notes 1121 (1985). The approach advocated by the Treasury has been criticized. See, e.g., Brookes D. Billman, Jr. \& Noel B. Cunningham, Nonbusiness State and Local Taxes: The Case for Deductibility, 28 Tax Notes 1107 (1985); Edward A. Zelinsky, The Deductibility of State and Local Taxes: Income Measurement, Tax Expenditures and Partial, Functional Deductibility, 6 Am. J. Tax Pol. 9 (1987). The resulting compromise in 1986 was to eliminate deductibility only for sales taxes. In the current session of Congress, major tax reform is again being actively discussed, and some prominent proposals would eliminate individuals' ability to deduct state and local taxes. See, e.g., USA Tax System, 66 Tax Notes 1481, 1523 (Special Supp. 1995); see also id. at 1548 (proposed elimination of business deduction for many state and local taxes).

${ }^{7}$ The revenue cost of deductibility is its most salient feature, but tax rates can be adjusted in an offsetting manner, leaving the appropriate relative treatment of taxpayers who pay differing amounts of state and local taxes as the central question. See infra note 30 . Indeed, proposed and actual elimination of deductibility of state and local taxes were to provide much of the revenue for tax reform that was contemplated and implemented in the 1980s, with the revenue used to fund lower rates (in a purportedly distribution-neutral manner). See also infra text accompanying note 198. (In addition, effects on work incentives are similar, because deductibility lowers the effective combined marginal rates of state and local taxes.)

8 See, e.g., sources cited supra note 6 . 
tax policy arguments are grounded more directly in modern incidence analysis. ${ }^{9}$ Second, more attention is devoted to what is financed by state and local taxes. ${ }^{10}$ Third, the desirability of deductibility is assessed not only by reference to whether it is required by a conceptually pure income tax but also in terms of how it serves underlying objectives of the income tax..$^{11}$

Commentators increasingly agree that an important factor bearing on the appropriateness of deductibility is whether individuals' state and local tax payments are closely related to the public services that individuals receive. Some suggest that the match is good, so that state and local taxes can be viewed as payments for government services. Just as individuals are not permitted to deduct expenditures on ordinary consumption, they should receive no deduction for consumption purchased through the government; hence, state and local taxes should not be deductible. Others question the connection between taxes paid

${ }^{9}$ See, e.g., Local Provision of Public Services: The Tiebout Model After Twentyfive Years (George R. Zodrow ed., 1983); Peter Mieszkowski \& George R. Zodrow, Taxation and the Tiebout Model: The Differential Effects of Head Taxes, Taxes on Land Rents, and Property Taxes, 27 J. Econ. Lit. 1098 (1989); Robert W. Wassmer, Property Taxation, Property Base, and Property Value: An Empirical Test of the "New View," 46 Nat'l Tax J. 135 (1993). For a survey covering these and other issues relevant to fiscal federalism, see Richard A. Musgrave \& Peggy B. Musgrave, Public Finance in Theory and Practice chs. 27-29 (5th ed. 1989), Wallace E. Oates, Fiscal Federalism (1979), David E. Wildasin, Urban Public Finance (1986), and Daniel L. Rubinfeld, The Economics of the Local Public Sector, in 2 Alan J. Auerbach \& Martin Feldstein, Handbook of Public Economics ch. 11 (1987). Although the literature on local public finance rarely receives extensive attention in legal publications, there are exceptions. See, e.g., Robert P. Inman \& Daniel L. Rubinfeld, The Judicial Pursuit of Local Fiscal Equity, 92 Harv. L. Rev. 1662 (1979).

${ }_{10}$ Zelinsky, supra note 6, devotes substantial attention to this issue as well as the next, although his approach is quite different from that here, as discussed infra note 27.

${ }^{11}$ A growing literature has emphasized the importance of basing arguments directly on the objectives of the tax system rather than simply invoking conceptual definitions of income. See, e.g., Thomas D. Griffith, Should "Tax Norms" Be Abandoned? Rethinking Tax Policy Analysis and the Taxation of Personal Injury Recoveries, 1993 Wisc. L. Rev. 1115; Thomas D. Griffith, Theories of Personal Deductions in the Income Tax, 40 Hastings L.J. 343 (1989) [hereinafter Griffith, Personal Deductions]; Louis Kaplow, Human Capital Under an Ideal Income Tax, 80 Va. L. Rev. 1477 (1994); Louis Kaplow, The Income Tax as Insurance: The Casualty Loss and Medical Expense Deductions and the Exclusion of Medical Insurance Premiums, $79 \mathrm{Cal}$. L. Rev. 1485 (1991); Joseph E. Stiglitz \& Michael J. Boskin, Impact of Recent Developments in Public Finance Theory on Public Policy Decisions, 67 Am. Econ. Rev. 295 (1977). 
and benefits received. If state and local taxes are contributions to government that hardly correlate with benefits received, such taxes should be deductible. Part I considers these two cases as benchmarks for further analysis. This Part suggests that proper income measurement when taxes do not equal benefits is achieved in a manner different from providing deductibility.

Part I also assesses arguments about deductibility by reference to the ultimate objectives the federal income tax serves. Most of the analysis in this Article and much in the hterature address whether deductibility is appropriate to implement a conceptually pure tax on "income." Presumably, most references to "income" contemplate some notion of ability to pay: Is an individual who earns $\$ 30,000$ and pays $\$ 1,000$ in state and local taxes in the same situation as one who pays no such tax and earns $\$ 30,000$, $\$ 29,000$, or some other amount? Part I suggests that arguments for adjusting income measurement in light of state and local taxes depend on premises and arguments that often are rejected in other contexts. ${ }^{12}$

Part II examines the process by which particular distributions of taxes and benefits arise. ${ }^{13}$ The analysis emphasizes that the levels and composition of both taxes and benefits are endogenous: they are determined by mdividuals' locational decisions and by local government politics. In addition, the incidence of taxes is not always obvious. The "benefit view" of the property tax, for example, holds that the tax is borne by residents in an amount reflecting governmental benefits, whereas the "new view" holds that, on average, the property tax is borne by all capital. ${ }^{14}$ Even within the new view, however, it still is possible

12 A definitive resolution of the issue is difficult and beyond the scope of the present investigation. The relevance of much of the analysis in the remainder of the Article, however, depends upon the position one takes on this issue. For example, an argument that a particular tax on business may have an incidence that results in de facto deductibility to individuals would be no cause for concern if deductibility is favored but provides a justification for new rules if it is not.

13 The discussion draws on a body of theoretical and empirical literature-much concerning the property tax-that addresses the incidence of taxes and benefits. See, e.g., sources cited supra note 9.

14 The traditional, classical, or "old" view that the property tax is borne by occupants of housing is related to aspects of the new view. In particular, as explained in Subsection II.B.1, the new view holds that differences in tax rates between jurisdictions will produce differences in rental prices. See, e.g., Charles E. McLure, Jr., The 
that taxes equal benefits. And when they do not, accurate income measurement may entail a set of deductions (and imputations of income) that would be the same for renters (who implicitly pay the taxes through higher rents) as for owner-occupiers.

Part III examines state and local taxes on business, which are deductible as ordinary business expenses. 15 Many taxes nominally imposed on businesses might in fact be borne by consumers or workers. To the extent such taxes finance benefits for those individuals, the appropriateness of business deductibility requires further analysis. Relatedly, some taxes will have the same incidence regardless of whether they are imposed nominally on businesses or on individuals. In such cases, the availability of de facto deductibility under current and most proposed rules may depend on how states and localities choose to describe a given tax.

Part IV focuses on income redistribution undertaken by state and local governments. Redistribution is involved whenever the state and local taxes that individuals pay do not equal the benefits they receive. ${ }^{16}$ The analysis in Parts I and II, as well as that in the hiterature, assumes that such redistribution affects abihty to pay and thus should be reflected in taxable income, as by allowing deductibility of state and local taxes. Part IV examines whether this conclusion follows; the reasoning depends on why states and localities in a federal system engage im redistribution.

Part V considers the existence of interjurisdictional spillovers from state and local activity and their relevance to deductibility. (Redistribution, the subject of Part IV, is an important potential source of spillovers.)

If the analysis in Parts IV and V provides some support for deductibility, it is primarily because deductibility subsidizes desirable expenditures. Part VI briefly considers whether deductibility is an effective subsidy. It also assesses the efficiency of

\footnotetext{
"New View" of the Property Tax: A Caveat, 30 Nat'l Tax J. 69 (1977); Mieszkowski \& Zodrow, supra note 9, at 1117-19. Thus, the old view will not be addressed separately here.

15 In some instances, tax payments must be capitalized. See I.R.C. $\$ 263$ A(a) (1994). The focus in the present Article, however, is on whether any sort of deduction should be permitted rather than on the timing of deductions.

${ }^{16}$ See infra note 44 . Conversely, if state and local taxes were perfect benefits taxes, there would be no redistribution.
} 
deductibility with regard to its effects on the size of state and local public sectors and on the pricing of publicly provided goods and services.

Much of this Article suggests that arguments favoring deductibility of state and local taxes are weaker than most advocates claim even granting their most commonly offered assumptions. The simplest argument against deductibility - that state and local taxes equal benefits received-is stronger in principle than most arguments favoring deductibility, but the factual predicate of the usual form of the argument is inaccurate, perhaps to a significant extent.

Definitive conclusions about the appropriateness of deductibility prove difficult to reach. First, a range of conflicts among different theories about tax and benefit coinposition and incidence stand unresolved by empirical evidence. ${ }^{17}$ Second, the efficiency consequences of deductibility are of uncertain significance; it is not even certain whetler they are positive or negative. Finally, whatever is correct in principle, the range of available alternatives inay be limited by politics.

\section{BENCHMARK CASES AND ABILITY TO PAY}

Sections A and B examine two benchmark cases: taxes equal to benefits within the local jurisdiction and taxes unrelated to benefits. (For convenience, "local" is used as a shorthand for "state or local" in much of the discussion to follow.) In each case, the appropriate federal income tax treatment of state and local tax payments is determined by the norms used in conventional tax policy analysis. These two cases are those the literature most cominonly addresses, and they constitute simple, polar cases that are useful reference points in the Parts that follow. The analysis in Section B also addresses intermediate cases. (As long as taxes do not precisely equal benefits, it is commonly believed that soine deduction is appropriate.)

Section $\mathrm{C}$ considers whether adjustments to taxable income that reflect differences between taxes paid and benefits received are indeed justified if taxable income is designed to reflect tax-

17 It is plausible that the truth varies by context: suburbs may be better explained by one set of theories and large cities by another. 
payers' ability to pay - their economic well-being. The analysis suggests that the argument for adjustments depends upon premises that are often rejected im other contexts. It is beyond the scope of the present project to attempt a definitive analysis.

\section{A. Taxes Equal to Benefits within the Jurisdiction}

Local taxes finance local expenditures on goods and services for residents. Thus, residents' benefits will have some correlation with their taxes. Indeed, each resident's taxes and benefits may be equal in value. ${ }^{18}$ After all, taxes and public expenditures are chosen by residents through the pohitical process. ${ }^{19}$ In addition, individuals "vote with their feet." Individuals whose taxes exceed benefits received have an incentive to move to another jurisdiction, and jurisdictions will attract individuals who would be permitted to pay less than their share. If there is sufficient mobility and a sufficient variety of jurisdictions from which to choose, one might expect the equilibrium to be one in which taxes equal benefits. These arguments are essentially the ones offered to justify denying deductibihty in Treasury I and Treasury II, ${ }^{20}$ the executive branch proposals for tax reform preceding the 1986 Tax Reform Act.

18 This statement ignores consumer surplus. More precisely, benefits would be greater than or equal to payments, with equality at the margin. For private goods, this result arises from consumer choice in consumption. For public goods, this result holds with efficient provision and Lindahl pricing: more of a public good is provided until the point at which the marginal cost equals the sum of individuals' marginal willingness to pay, and each individual pays (at the margin) a share equal to her marginal willingness to pay. See, e.g., Harvey S. Rosen, Public Finance 120-21 (3d ed. 1992); Paul A. Samuelson, A Pure Theory of Public Expenditure, 36 Rev. Econ. \& Stat. 387 (1954).

19 On this ground, Peacock has suggested that (even at the national level) the presumption that the benefits of public goods have the same distribution as taxes is "just as plausible a starting-point for discussion of the allocation of indivisible benefits as one which ignores any reference to the political bargaiming process." Alan Peacock, The Treatment of Government Expenditure in Studies of Income Redistribution, in Public Finance and Stabilization Policy 151, 164 (Warren L. Smith \& John M. Culbertson eds., 1974).

${ }^{20} 2$ Treasury I, supra note 6, at 63; Treasury II, supra note 6, at 63; see Charles R. Hulten \& Robert M. Schwab, A Haig-Simons-Tiebout Comprehensive Income Tax, 44 Nat'l Tax J. 67 (1991). 
If taxes equal benefits, most commentators would agree that taxes should not be deductible. The argument can be expressed in two ways. First, purchases of public goods are analogous to purchases of private goods: both entail consumption. Thus, if one wishes to tax income-equal to consumption plus accumulation $^{21}$-one must allow no deduction for consumption expenditures of any kind. If one permitted a deduction for expenditures on pubhic but not private goods, economic distortion would result. Public goods provision would be excessive because expenditures to purchase them would be subsidized.22

Second, it might be said that taxes reduce abihty to pay but benefits from one's local goverument are income: taxes should be deductible and benefits mcluded as income. Although im the abstract it may seem difficult to measure benefits, ${ }^{23}$ in this case the amount of taxes provides a precise measure. Rather than allowing a deduction and inclusion of equal amounts, it is simpler just to ignore both benefits and taxes, thereby denying a deduction for state and local taxes. ${ }^{24}$

Coinmentators generally agree with this reasoning. In the case of user charges, as when a municipality charges residents for trash removal, a consensus favors nondeductibility. Similarly, inost analysts favor the nondeductibility of gasoline taxes, which approximate a user charge for roads. ${ }^{25}$ Many commentators differ, however, regarding the assumption that individuals' payments of general taxes-namely, property, sales, and income taxes-equal the value of benefits received. The implications of this disagreement will now be explored.

${ }^{21}$ Henry Simons, Personal Income Taxation 50 (1938); see Robert Murray Haig, The Concept of Income, in The Federal Income Tax 1, 7, 11 (Robert Murray Haig ed., 1921).

22 See, e.g., 2 Treasury I, supra note 6, at 62; Treasury II, supra note 6, at 63-64; Robert C. Ellickson, Cities and Homeowners Associations, 130 U. Pa. L. Rev. 1519, 1575, 1578-79 (1982).

${ }^{23}$ See, e.g., Henry Aaron, Comments, in Comprehensive Income Taxation 30, 31-32 (Joseph A. Pechman ed., 1977).

${ }^{24}$ See, e.g., Billman \& Cunningham, supra note 6, at 1111.

${ }^{25}$ See, e.g., Bradford \& the U.S. Treasury Tax Policy Staff, supra note 1, at 86; William Vickrey, Agenda for Progressive Taxation 94 (1947); S. Rep. No. 1263, 95th Cong., 2d Sess. 57 (1978). Deductibility of gasoline taxes was eliminated by Pub. L. No. 95-600, § 111(a), 92 Stat. 2763, 2777 (1978). 


\section{B. Taxes Unrelated to Benefits within the Jurisdiction}

\section{Basic Analysis}

General state and local taxes are not directly tied to benefits. Rather, they appear to be largely independent of benefits. Thus, a resident who lives in a mansion pays much greater property taxes than one who lives in a small house, yet they have access to the same schools, parks, and pohice department. Similarly, rich state residents pay far more than poor residents in sales and income taxes, yet they have access to the same roads and state universities. Contrary to the taxes-equal-benefits view, therefore, one might hypothesize that available benefits are roughly equal among residents of a given jurisdiction, which implies that taxes are unrelated to benefits. ${ }^{26}$

Many argue that if state and local tax payments are unrelated to benefits, those payments should be deductible. ${ }^{27}$ In

${ }^{26}$ As a practical matter, if benefits are tangibly the same and provide equal utility to residents, they will have a higher monetary value to those with higher income (who tend to pay more property, sales, or income taxes) due to income effects. See infra note 33 .

27 See, e.g., Musgrave \& Musgrave, supra note 9, at 345; George F. Break, Tax Principles in a Federal System, in The Economics of Taxation 317 (Henry J. Aaron \& Michael J. Boskin eds., 1980); Boris I. Bittker, Income Tax Deductions, Credits, and Subsidies for Personal Expenditures, 16 J.L. \& Econ. 193, 200-01 (1973). Billman and Cunningham argue that:

only two basic solutions are available: (1) Allow the deduction for state and local taxes, except in cases in which there is an ascertainable relationship between the tax payment and the benefit received; or (2) Disallow the deduction completely on the assumption that the predominant portion of state and local taxes involves a direct correlation between benefits and tax payments.

Billman \& Cunningham, supra note 6, at 1113 (footnotes omitted). They do note the possibility of intermediate approaches, like one described by John F. Due, Personal Deductions, in Comprehensive Income Taxation, supra note 23, at 37, 51-52, wherein taxpayers would be permitted a deduction above a floor. See Billman \& Cunningham, supra note 6, at 1113 n.23; see also Bradford \& the U.S. Treasury Tax Policy Staff, supra note 1 , at 85 (making a similar suggestion as an alternative to its preferred proposal). As suggested in this Subsection, however, none of these approaches constitutes a reasonable first approximation of taxable income even accepting the premises these authors offer.

An intermediate approach closer to that explored here is offered in Zelinsky, supra note 6. For example, he states that "[t]here should not be a deduction for taxes financing public services only yielding benefits for the general community when those benefits exceed the socially accepted minimum standard of living, e.g., recreational services." Id. at 10-11. His approach focuses on the character of the public activities funded by state and local taxes, see id. at 10, despite his purported focus on income measurement. See id. Although Zelinsky sees the approaches as consistent-indeed, 
this case, tax payments do not constitute consumption; rather, consumption (the value of local benefits) is independent of the taxes one pays. Those who pay taxes have lower economic

that one is implied by the other-the difference is significant. For example, Zelinsky would allow a deduction for basic educational outlays. See id. at 10,40-42. If basic outlays were deemed, for example, to be $\$ 4,000$ per pupil, then taxpayers in jurisdictions spending $\$ 4,000$ per pupil receive a deduction for the full amount whereas those in jurisdictions spending $\$ 3,000$ get a lesser deduction (because in no event may there be a deduction for more than is actually spent). As a result, a taxpayer in the latter town with $\$ 1,000$ less income than one in the former town would show the same taxable income (gross income is $\$ 1,000$ less and deductions are $\$ 1,000$ less), even though she earned less and, accordingly, received poorer public services to precisely this extent. (His logic applied to private expenditures-a comparison he uses, see id. at 25-would in principle give a low-income individual a smaller personal exemption if she spent less on food than is assumed to be required for a minimum standard of living.) Zelinsky's argument is applicable to income measurement only when applied to expenditures that address factors reducing the standard of living relative to some norm. For example, he suggests that greater expenditures on police services may not be a sign of enhanced well-being to the extent they reflect a greater crime problem rather than greater public safety compared to jurisdictions with lower expenditures. See id. at 24. Thus, one might justify part of the deduction for state and local taxes as providing a proxy for differences in costs and benefits of living in different jurisdictions. This subject is discussed further in Subsection C.2. (See particularly note 65.) Zelinsky also calls for deductibility when taxes finance "public functions principally benefiting a discrete segment of the populace rather than the community as a whole, e.g., welfare, as such redistributive services do not generate the types of disparities with which the tax is concerned." Id. at 10; see id. at 32-33. Redistribution is more directly relevant to the question of income measurement, al though as explained in the text to follow and in Part IV, it is not obvious that simple deductibility follows in this case.

McCombs advocates deductibility for the amount of tax payments in excess of that which funds direct benefits. See J.B. McCombs, New Federal Tax Treatment of State and Local Taxes, 19 Pac. L.J. 747, 755 (1988). His approach differs from the appropriate treatment described im this Section in two respects: only "direct" benefits (limited to programs that provide at least proportionate direct benefits to middle class taxpayers, the ones who itemize, see id. at 760) give rise to nondeductibility, and no account is made of the remainder (i.e., the deduction given to a taxpayer who pays taxes but does not receive benefits is not matched by an inclusion for those who receive benefits in excess of the taxes they pay). In short, for other than direct benefits, his approach is one of simple nondeductibility. The principle reason given is one of practicality with regard to identifying and quantifying indirect benefits. See id. at 757. (Indeed, practical considerations lead McCombs to propose deductibility above a $\$ 500$ floor, see id. at 761-64, which is virtually equivalent to allowing full deductibihty and uniformly shifting the rate schedule or exemption amounts for itemizers; differences in taxes and benefits across jurisdictions are ignored entirely.) This common feasibility objection implicitly assumes that the best approximation of a local resident's benefits is zero rather than the taxes they pay or some simple adjustment of the sort described in this Subsection. See infra note 30. 
well-being to the extent of their payments, so a deduction is necessary if ability to pay is to be ineasured properly.

The foregoing analysis, however, is incomplete. Although it may justify the deductibility of taxes, the argument would not warrant excluding benefits froin incoine. Because everyone's benefits are, by assumption, the same, it may seem immaterial whether there is such an inclusion. (An adjustment in the rate schedule applicable to everyone could take this into account. ${ }^{28}$ ) But this response is correct only if there is a single local jurisdiction, in which case probleins of federahisin would be trivial. Otherwise, a taxpayer who hives in a wealthy jurisdiction will benefit froin schools, parks, and police protection that are better than those available to one who hives in a poorer jurisdiction and pays the same amount of tax. Allowing deductibility while ignoring benefits would fail to capture this difference.

Even when each resident's taxes are unrelated to benefits, residents' taxes are on average equal to residents' benefits within a given jurisdiction. ${ }^{29}$ As a result, if some residents' ability to pay is lower on account of their payment of taxes in excess of benefits, other residents' ability to pay must be higher on account of their receipt of benefits in excess of taxes. If the former are entitled to a deduction for the difference between taxes and benefits, the latter should be required to include the difference in incoine. 30

${ }^{28}$ For example, if $\$ 1,000$ of benefits is omitted for everyone, $\$ 1,000$ could be subtracted from the starting point of each bracket. If the benefits were per capita rather than per tax unit, one could subtract $\$ 1,000$ from each personal exemption.

${ }^{29}$ See the qualification concerning consumer surplus in note 18 and that concerning public expenditures that offset lower amenities in note 27 (discussing one of Zelinsky's arguments). In addition, jurisdictions may vary in the value of benefits produced on account of differences in scale economies or production costs; in these instances, the analysis in Section I.C, particularly the comparison to cost-of-living differences, would be relevant. One could also argue that government is inefficient, and thus benefits are less than average taxes. If such a view were accepted, then a figure less than $T$, reflecting the extent of waste in the relevant jurisdiction, would be subtracted in the formulation offered below. No matter how inefficient local government is believed to be, however, it is implausible that most resources are wasted and that individuals in wealthier jurisdictions receive no more than those paying taxes at the same rates in poorer jurisdictions.

${ }^{30}$ Implicit in some arguments for deductibility is the view that when error is unavoidable, it is best to err in favor of the taxpayer. What is overlooked is that, given a target level of revenue (to spend on public goods or redistribution), reductions in one taxpayer's burden must be made up by increases in others' burdens. The problem 
To implement this approach, one could allow each taxpayer a deduction of $T_{i}-T$, where $T_{i}$ is the tax paid by the individual to the locality, and $T$ is the average level of taxes paid by all individuals in the locality 31 - which is assumed here to equal benefits received. Those who pay relatively high taxes will have a $T_{i}$ that exceeds $T$, so they will receive a deduction to that extent. For those who pay relatively low taxes, $T_{i}-T$ will be negative, indicating an inclusion.

To illustrate this scheme, suppose that towns A and B each have only two residents. In $\mathrm{A}$, Resident 1 pays $\$ 4,000$ in tax, and Resident 2 pays $\$ 2,000$. T is $\$ 3,000$; Resident 1 takes a $\$ 1,000$ deduction, and Resident 2 has a $\$ 1,000$ inclusion. In $\mathrm{B}$, Resident 1 and Resident 2 each pay $\$ 5,000$. In this case, $T$ is $\$ 5,000$, and neither resident has a deduction or inclusion. Observe that soine individuals (here, Resident 1 in A) may have a higher deduction than others who pay inore taxes (those in B). The reason is that deductions are adjusted for benefits. This approach, therefore, avoids the objection that deductibility favors those who live in high-benefit jurisdictions. ${ }^{32}$

\section{Intermediate Cases}

Suppose that, within jurisdictions, individuals who pay inore tax receive inore benefits, but the benefits do not fully reflect

of defining income in designing a tax base is not one that involves a trade-off between generosity to taxpayers and to the governinent. Rather, the problem is how to allocate burdens ainong taxpayers. Thus, taking revenue requirements into account, it will always be true (as a matter of definition) that measurement errors are minimized by the best approximation, rather than by providing treatment at an extreme (even if the chosen extreine is less erroneous on average than the opposite extreme). See generally Kaplow, supra note 4 (income ineasurement, not revenue, relevant in setting standard deduction); Louis Kaplow, Accuracy, Complexity, and the Income Tax, Harvard Law School Program in Law and Econoinics Discussion Paper No. 139 (1994). (A more complete analysis would account for the fact that when there is uncertainty, distributive objectives may not be achieved optimally by using the mean estimate; when the variance is greater or when the individual's income is lower, a figure below the mean will tend to be more appropriate.)

31 When the composition of taxable units differs (for example, single individuals versus married couples), it would be necessary to estimate how benefits varied among such units to allocate this tax-based estinate of total benefits. See also infra Subsection 4 (demographic redistribution).

${ }^{32}$ See infra Section VI.A. There still will be differences under an income tax with graduated rates and itemization: large deductions, received by high-income taxpayers, will be worth more than the cost of large inclusions to low-income taxpayers. 
the difference in taxes they pay. For example, those who have more luxurious houses may benefit more from police protection and road quality. ${ }^{33}$ As a result, the $T_{i}-T$ deduction would be too large (as would the corresponding inclusion for those who pay low taxes). One might instead allow a deduction of $\alpha\left(T_{i}\right.$ T), where $\alpha$ is less than one. ${ }^{34}$

Suppose instead that lower-income residents' benefits are higher than average. This would be true when tax revenues fund welfare programs. Also, public schools might be used by the poor and middle class, whereas the rich might opt for private schools. In this case, $\alpha$ could be set to exceed one. ${ }^{35}$ Then the rich would get a deduction exceeding the difference between their tax payment and the jurisdictional average, and the inclusion for lower-income individuals would be greater.

At this point, the existence and magnitude of any deduction or inclusion on account of state and local taxes and benefits appears to depend on the empirical question of the incidence of benefits relative to taxes. Reliable empirical evidence is difficult to obtain, so the question of incidence is addressed in large part by theory. This topic is considered in Parts II and III.

${ }_{33} \mathrm{Also}$, due to income effects, the rich place a higher monetary value on a given level of public services. It is familiar that for most goods and services, individuals demand a greater quantity at a given price the higher is their income. This implies that the marginal valuation (measured in dollars) for each unit is higher, even though the utility it generates is the same. This property is related to the diminishing marginal utility of income, which implies that one is willing to pay more for a given good or service generating a given amount of utility the higher is one's income, because when income is higher the forgone utility from alternative expenditures is lower.

34 This adjustment assumes that the relationship between benefits and taxes is linear; if it is not, more complex adjustments could be employed.

${ }^{35}$ The second benchmark, of taxes unrelated to benefits, is thus not really a polar case. That of taxes negatively correlated to benefits, considered here, is more extreme. 


\section{Fiscal Equalization ${ }^{36}$}

The treatment of taxes under the second benchmark that has just been described in the preceding Subsections assumes that average taxes paid in the jurisdiction provide a measure of benefits in the jurisdiction. But this is typically inaccurate, especially for localities, because average local tax payments do not include benefits conferred by grants and other support received from higher levels of government. ${ }^{37}$

To illustrate how such grants can be accounted for under the second benchmark, consider the case of state aid to local governinent. (A more complete account requires consideration of federal aid $^{38}$ and whether higher levels of government exercise influence on spending at lower levels through matching grants and mandates. ${ }^{39}$ ) In applying the second benchmark to state taxes, benefits will not be uniform if aid to localities is not uniform; residents of localities that receive more state aid receive more benefits. To account for this, one can combine state and local taxes paid in determining $T_{i}$ for eacli taxpayer and also take into account state aid in determining $\mathrm{T}$ for each locality. To take an extreme case, suppose that state aid was fully equalizing, so that benefits per capita were the same in each locality. Then, the relevant $T$ in eacli locality would be the sane: the average of state and local taxes combined. Individuals paying combined state and local taxes above the average for the state would re-

${ }^{36}$ For a theoretical analysis, see Robin Boadway \& Frank Flatters, Efficiency and Equalization Payments in a Federal System of Government: A Synthesis and Extension of Recent Results, 15 Can. J. Econ. 613 (1982). For information on the increase in fiscal equalization in recent decades, see Andrew Reschovsky, Fiscal Equalization and School Finance, 47 Nat'l Tax J. 185, 190 (1994). For discussion of how capitalization inay offset soine effects of equalization, see Helen F. Ladd \& John Yinger, The Case for Equalizing Aid, 47 Nat'l Tax J. 211, 218-20 (1994). For criticism of many of the reasons given for fiscal equahization, see William $\mathrm{H}$. Oakland, Fiscal Equalization: An Empty Box, 47 Nat'l Tax J. 199 (1994).

37 See, e.g., Zelinsky, supra note 6, at 43 \& n.91; infra Sections IV.A and V.A.

38 As discussed in note 44 , if ability to pay is measured for distributive purposes, it is appropriate to treat the portion of federal taxes funding benefits received froin the federal government separately. To accoinplish this, one inust allocate benefits to recipients in order to determine what portion of recipients' taxes should be associated with financing benefits.

${ }^{39}$ For a discussion of how matching grants and mandates may affect the relationship between expenditures made and the value of benefits produced, see note 187 . 
ceive deductions to that extent, and those paying less than the average would include the difference in their taxable income.

\section{Demographic Redistribution}

This Section, as well as the rest of the Article, generally discusses redistribution as though it involves transfers across $\mathrm{m}$ coine levels, particularly from the rich to the poor. But the logic of the analysis does not depend on this, and a significant portion of state and local spending may mvolve a sort of demographic redistribution. The most important instance is public education, which favors families with children (and larger numbers of children) over taxpaying units that do not have children.40

The main effect on the second benchmark would be that the use of $\mathrm{T}$, the average level of taxes, as a proxy for a typical taxpaying unit's benefits may be highly maccurate..$^{41}$ One could imagine a simple adjustnient; for example, the portion of $\mathrm{T}$ spent on elenientary schools might be allocated among taxpaying units based upon the number of school-age children (so none of that portion would be allocated to childless taxpaying units and a greater amount would be allocated to families with many children). ${ }^{42}$ This reinterpretation of $\mathrm{T}$ would make apphicable the analysis of the second benchmark that appears in the rest of the Article.

40 Among families with children, public education disfavors those who do not use public schools. There are other forms of demographic redistribution, such as other spending that targets children (playgrounds) or spending on the elderly. See also supra note 31 (describing problem of allocating benefits among different types of taxable units).

41 On a lifetime basis, the approximation may not be as inaccurate, particularly for individuals who live much of their lives in jurisdictions providing a similar mix of services.

${ }^{42}$ See Zelinsky, supra note 6 , at 41 . One might object to this approach because the current income tax makes little allowance for children (except in the separate tax schedule for heads of households, see I.R.C. \& 1(b) (1994)). Such a proposal, however, might be accompanied by an increase in the value of exemptions for children. (Indeed, one might justify the current low exemptions by the fact that a significant portion of the expenses of raising children are publicly borne, with the benefits excluded from the tax system.) 


\section{Summary}

The preceding Subsections have suggested numerous qualifications and complications concerning the second benchmark, which calls for a deduction of $T_{i}-T$ rather than a simple deduction of $\mathrm{T}_{\mathrm{i}}$. Others will be raised elsewhere in the Article. Obviously, many administrative questions would have to be resolved if the second benchmark were actually to be implemented. Such questions will not be examined here. The present investigation does not advocate adoption of the second benchmark or any other particular regime. Rather, it seeks to illuminate the implications of a range of arguments concerning deductibility, taking into account the actual imcidence of taxes and benefits and the criteria that are appropriate in evaluating income tax provisions. For this purpose, it will be useful to continue to refer to the second benchmark simply as entailing a deduction of $T_{i}-T$, keeping in mind that $\mathrm{T}$ is a stand-in for the best feasible proxy of each individual's actual benefits (which might liave been denoted $B_{i}$ ) and that other issues concerning the benclimark are being put to the side.

\section{Ability to Pay and Economic Well-Being}

The discussion in Sections A and B suggests wliat treatment of state and local taxes under the federal income tax is "appropriate" in light of various assumptions about the relationship between taxes paid and benefits received. But no evaluative norm was elaborated. The criterion implicitly being invoked is a familiar notion of ability to pay, which is understood to refer to taxpayers' economic well-being. ${ }^{43}$ The motivation for using such a criterion arises from the redistributive function of the income tax: a measure of well-being is required to determine who should pay how mucli to whom. ${ }^{44}$ For this purpose, all

${ }^{43}$ For an illustrative discussion and references to the familiar statements, see Zelinsky, supra note 6 , at $18-21$.

${ }^{44}$ Financing public goods and services (other than redistribution itself) is implicitly assumed to be accomplished by benefits taxation. The distinction between financing benefits and redistribution is conceptually useful but is not a practical restriction. As will be discussed, see infra text accompanying note 153 , one can describe any tax scheme in a way that separates the benefit-financing and redistributive functions. See Louis Kaplow, Should the Government's Allocation Branch Be Concerned About the 
would agree that a taxpayer who receives wage income of $\$ 30,000$ is similarly situated to one who is self-employed, grosses $\$ 50,000$, and incurs $\$ 20,000$ of business expenses. Measures of well-being are, however, notoriously ambiguous in other settings. When one assesses an issue as complex and controversial as the deductibihity of state and local taxes, therefore, it is important to specify and defend one's criterion carefully. 45 Subtle differences that are irrelevant in some contexts inay be important here. ${ }^{46}$

\section{Competing Bases for Valuation}

The principal problem concerns whether one should impute values based on payments or infer values from actions. To put it more concretely, consider an individual who moves into a jurisdiction in which she must pay $\$ 4,000$ in taxes to finance benefits that cost $\$ 3,000$ per capita and are equally available to

Distortionary Cost of Taxation and Distributive Effects, Harvard Law School Program in Law and Economics Discussion Paper No. 137 (1993).

This perspective differs from a more common one in which ability to pay is said to be relevant to determine citizens' appropriate contributions to finance government activity. It is not clear, however, why citizens should, for example, pay a percentage of their income for goods that happen as a matter of existing technology to be "public"-say, roads - but pay the same absolute amount as everyone else for technologically "private" goods - such as cars (if they buy the same quality of car). Suppose that tolls measuring congestion and road wear could costlessly be charged, with resulting efficiency gains from more efficient allocation of road usage, and that the revenue was sufficient to finance the roads. Is the availability of such pricing technology a good normative reason for changing the income distribution? (Individuals with differing incomes making equal use of roads would pay the same amount rather than an amount in proportion to their income.)

In principle, the measure of well-being should be derived from the norms of distributive justice that motivate the redistributive function of the income tax. If a welfarist approach is adopted-e.g., a utilitarian or Rawlsian approach, see Joseph Bankman and Thomas Griffith, Social Welfare and the Rate Structure: A New Look at Progressive Taxation, $75 \mathrm{Cal}$. L. Rev. 1905 (1987)-the perspective separating benefits financing and redistribution suggested here would follow. In the discussion below, however, it will be seen that not all distributive theories imply the same approach to the measurement of well-being.

${ }_{45}$ See sources cited supra note 11 (concerning the need to be explicit in specifying tax objectives) and infra note 61 (on different distributive criteria).

46 The analysis to follow pursues only the question whether some sort of deduction system, particularly that of the second benchmark, best measures economic well-being. There is the further question of whether, taking into account the adverse incentive effects of redistributive taxation, such an adjustment is best. (This issue is not already captured implicitly in setting tax rates because it need not be true that all adjustments designed to better measure well-being would affect incentives to the same extent.) 
and used by all residents. 47 The analysis of the second benchmark stipulated that a $\$ 1,000$ deduction is appropriate in this case. ( $T_{i}$ is $\$ 4,000$ and $T$ is $\$ 3,000$, so $T_{i}-T$ is $\$ 1,000$.) The reason is that this individual's economic well-being is $\$ 1,000$ lower on account of taxes and public services. Two comparisons support this claim. First, the taxpayer might be seen as $\$ 1,000$ worse off than one who did not live in the jurisdiction and thus did not pay $\$ 4,000$ in taxes and receive $\$ 3,000$ in public benefits. Second, the taxpayer might be compared to the average taxpayer in the jurisdiction, who pays only $\$ 3,000$ to receive the same benefits.

An alternative argument, however, suggests that such differences in taxes and benefits be ignored, resulting in no deduction or imclusion for any taxpayer. The point is that we should not impute a value of $\$ 3,000$ for the services this individual receives. Rather, we should infer the value froin what she actually pays, which is $\$ 4,000$. Such a process of inference guarantees that taxes will equal benefits for all individuals, so no adjustment would ever be required.

This approach is supported by analogy to the purchase of private goods. Individuals who buy goods on sale do not have their savings imputed as income. The reason in principle is that there is no reason to presume that the goods are worth any more than what is actually paid. Similarly, individuals who pay inore for goods are not perimitted a deduction for the excess they paid. The implicit presumption is that, typically, individuals who pay more get inore. For example, the higher price may reflect shopping at a convenience store, so that there is a benefit froin saving time.

The presumptions regarding consumers' purchasing decisions are justified by simple denıand analysis. Individuals purchase additional quantities of goods and services until the point at which their marginal cost-the price-just equals their inarginal benefit. Thus, whatever price individuals are charged, their marginal purchases will produce benefits that yield no surplus (and involve no loss). Their inframarginal purchases-the imitial quantities they purchase before reaching the stopping

${ }^{47}$ To simplify, income effects, see supra note 33, are ignored here as in the discussion of the benchmark case. 
point-generally yield positive net benefits, referred to as consumer surplus. Because consumer surplus cannot be observed, however, the tax system cannot take it into account. Moreover, one suspects that individuals with equal income probably benefit to a similar extent from consumer surplus, so no obvious inequity results. And, if there is inequity among equal-income individuals, there usually would be no way to correct it. 48

This approach has substantial force with respect to local taxes and public services, although there often are differences between the contexts of selecting jurisdictions and choosing among ordinary consumer goods. Most notably, one usually cannot choose the precise amount and composition of public services. This is because jurisdictional choices are absolutely limited and further constrained by factors such as information, job skills, and the location of family and friends. Sometimes, however, the same problem arises with private goods. ${ }^{49}$ Individuals choose among the available options. If some individuals seem to spend inore on food or automobiles, we are inchined to infer that the aggregate mix of what they buy, in light of their preferences, provides the best value for their money and a value at least equal to what they pay. Similar reasoning seems apphicable to the choice of local jurisdictions.

Another possibly miportant distinction between the contexts is that where one hives is related to work; as with commuting expenses, there is some mix of business and personal dimensions. To illustrate, suppose that one is indifferent between the public services provided by two towns. The taxes in $\mathrm{A}$ are $\$ 3,000$ and in $B$ are $\$ 4,000$, but jobs in one's line of work that are accessible from $B$ pay $\$ 1,500$ more than jobs accessible from $A$. The choice to live in $B$ is made because one earns $\$ 1,500$ more at a

48 Absent information about who receives more than average surplus, "correction" is as likely to increase error as to correct it. Moreover, because the marginal equity cost of errors generally increases with their magnitude (this is certainly plausible under most welfarist perspectives, see Kaplow, supra note 30 ), welfare is maximized by making no adjustment rather than by random adjustment.

If individuals at different income levels receive systematically different levels of consumer surplus and such differences are believed relevant, the appropriate adjustment would be to vary tax rates directly.

49 No health club has just the right mix of facilities, ambience, and location. No car has just the right size, options, and color. The restaurant with the best food is in the wrong location; the one with the best atmosphere has lousy desserts. 
cost of $\$ 1,000$ in taxes. In this situation, one could argue that the additional $\$ 1,000$ in taxes are a cost of earning incoine and therefore should be deductible. 50

Presumably, this sort of argument is usually rejected because it is difficult to determine when the facts are as stated. For example, an individual who would earn less in B would still choose to live there if she valued the benefits in $B$ sufficiently more than those in A.51 The implicit claim supporting a view that no adjustment should be made is that, when individuals are observed to pay more in taxes for public services, they are on average receiving more consumption in return, just as individuals who pay more in rent or at restaurants are presuined on average to benefit more. This claim is not, of course, completely accurate for any particular individual; rather, the argument is that this presumption is the most accurate among feasible characterizations, given the available information.

As is well known, the issues under discussion are hardly unique to the problem of state and local taxes. The problems concerning consumer surplus, imputed income, and unobservable nonpecuniary differences im jobs arise in connection with many aspects of income taxation. An appropriate resolution is beyond the scope of this narrower inquiry. It should be apparent, however, that even the more limited argument for deductions and inclusions presented in the context of the second benchinark depends on how these issues are resolved. Further considerations bearing on this issue in the context of state and local taxes are offered in the following Subsection and in the analysis in Parts IV and V concerning the use of state and local taxes to

50 Analogously, suppose that commuting expenses rather than taxes were $\$ 1,000$ higher in $B$. (That is, the low-paying job is closer to $A$, and the high-paying job is closer to $B$ but not as close to $B$ as the low-paying job is to $A$ : commuting expenses are $\$ 1,000$ higher for the good job near $B$.) Again, town $B$ is preferable because one nets $\$ 500$ more, and the argument would require that commuting expenses be deductible. See William A. Klein, Income Taxation and Commuting Expenses: Tax Policy and the Need for Nonsimplistic Analysis of "Simple" Problems, 54 Cornell L. Rev. 871, 884-85. (1969). But see infra note 51.

51 Similarly, one can revisit the argument developed supra note 50, which suggests that commuting expenses should be deductible on the ground that higher commuting expenses may be incurred to earn higher wages. The problem is that higher commuting expenses may be incurred to save time instead (by using a more expensive means of transport to arrive sooner) or they may be incurred to reside in an area with better amenities. 
finance redistribution and other activities that may involve interjurisdictional spillovers.

\section{Comparison to Cost-of-Living Adjustments}

Interjurisdictional differences in state and local taxes and benefits can be seen as an instance of the more general problem of regional cost-of-living differences. Suppose, for example, that the only difference between living in region $\mathrm{A}$ rather than region $B$ is that all goods and services are $5 \%$ more expensive in A. The cost residents bear is the same as it would be were there no real cost-of-living difference but instead all purchases in A were subject to a $5 \%$ sales tax. The major difference is that the sales tax revenue presumably funds benefits in $\mathrm{A}$. To the extent of any difference between taxes paid and benefits received, however, the cost-of-living analogy holds. Indeed, taxes are but one of many costs that differ among regions. Some literature on cost-of-living measurement has recognized this connection im addressing the need to take taxes and government benefits into account.52 The following discussion offers a brief analysis of pure cost-of-living differences to see what insight may be offered concerning whether the deductibility of state and local taxes is appropriate.

\section{a. Simple Cost-of-Living Adjustments ${ }^{53}$}

When costs are uniformly $5 \%$ ligher in $A$ than in $B$, should residents in $\mathrm{A}$ be allowed a deduction equal to $5 \%$ of income? To be more concrete, compare a worker in A who earns $\$ 21,000$ with one in B wlio earns $\$ 20,000$. In the absence of taxes, they have the same economic well-being (because $\$ 21,000$ in $\mathrm{A}$ has the same buying power as $\$ 20,000$ in $B$ ). Does it follow that the

52 See, e.g., Martin David, Measurement of the Cost of Living Including the Public Sector, 4 Annals Econ. \& Soc. Meas. 133-52 (1975); Joseph Gyourko \& Joseph Tracy, The Importance of Local Fiscal Conditions in Analyzing Local Labor Markets, $97 \mathrm{~J}$. Pol. Econ. 1208 (1989); Joseph Gyourko \& Joseph Tracy, The Structure of Local Public Finance and the Quality of Life, 99 J. Pol. Econ. 774 (1991).

${ }^{53}$ The analysis in this Subsection is developed at greater length in Louis Kaplow, Regional Cost-of-Living Adjustments in Tax-Transfer Schemes, Harvard Program in Law and Economics Working Paper No. 150 (1995) (forthcoming in 50 Tax L. Rev. 1 (1995). 
worker in A should be permitted an incoine tax deduction of $\$ 1,000$, reducing her $\$ 21,000$ of incoine to taxable incoine of $\$ 20,000$, indicating the same ability to pay as the worker in $B$ who earns $\$ 20,000$ ?

Such treatinent would be too generous, in the sense that it would result in the worker in A having a higher after-tax level of well-being than the worker in B. To see this, suppose that the incoine tax is a flat $10 \%$, so that $\$ 2,000$ is owed by both taxpayers given the posited adjustment. Observe that this equal nominal tax payment imposes a lower real burden on the worker in $A$, because $\$ 2,000$ given up to the government would not have bought as much (in real terms) in $A$ as in $B$. To put this another way, note that the ratio of their before-tax incomes, $\$ 21,000 / \$ 20,000$, is 1.05 , but their ratio of after-tax incomes if a deduction is allowed, $\$ 19,000 / \$ 18,000$, is 1.0556 .

Suppose instead that no deduction were allowed. Then the worker in A would pay $\$ 2,100$ in tax, for an after-tax incoine of $\$ 18,900$. Now, the ratio of their after-tax incoines is $\$ 18,900 / \$ 18,000$, or 1.05 . Thus, despite the real cost-of-hving difference, providing no deduction yields a result under which relative well-being is unaffected by the income tax. 54

If one modified the example to allow for progressive marginal rates or welfare payments to the poor, it can be demonstrated that the adjustment which preserves relative well-being after payment of taxes is not a deduction but instead involves changes that are equivalent to conventional indexing for inflation: 55 brackets and exemptions would be adjusted by the cost-of-living difference, as would welfare entitlements.

\section{b. Application to State and Local Taxes}

The analysis in the preceding Subsection indicates that benchInark treatment, which provides a deduction of $\mathrm{T}_{\mathrm{i}}-\mathrm{T}$ for the case in which all residents receive equal benefits, is incorrect on

${ }^{54}$ Another way to see why this result is correct is to note that the buying power of the $\$ 2,100$ paid in tax by the worker in $A$ is the same as that of the $\$ 2,000$ paid in tax by the worker in B. Each worker, therefore, has the same buying power before tax and gives up the same buying power in making tax payments, so it must be that their buying power is the same after tax.

55 See, e.g., Inflation and the Income Tax (Henry J. Aaron ed., 1976). 
its own terms for taxes on consumption, including the sales tax and arguably the property tax. If benefits are uniform and equal to $T$, they could be added to income, but the appropriate treatment of $\mathrm{T}_{\mathrm{i}}$ would be similar to that just described if the state and local taxes were proportional to income. ${ }^{56}$ (This is approximately true for sales taxes and is closer to the truth for property taxes than the opposite assumption that taxes are independent of income. ${ }^{57}$ ) It follows from the illustration in the preceding Subsection that a deduction of $T_{i}-T$ would be too large by this standard. 58

By contrast, with a typical state income tax, the analysis of the second benchmark would remain apphicable. In brief, the distimction between the two types of taxes is that taxes on consumption, hike the sales tax, already entail an implicit deduc-

56 To put this another way, assume that there is no federal income tax and an individual in jurisdiction $A$ pays a state sales tax at rate $t$ which funds a benefit of value T. An individual in jurisdiction $B$, which has no state tax and no state-funded benefit, would have the same level of well-being if he had income 1-t as high, augmented by the value of the benefit. If one applied the federal tax regine described in the text-including the benefit in taxable income, allowing no deduction for the state tax, and making infiation-indexing-type adjustments to the tax schedule (there would be none if it were a flat-rate federal income tax with no exemption)-the after-tax effective consumption (actual consumption of private goods plus the value of any public benefit) would continue to be the same for both individuals. (There is a slight detail omitted: because the public benefit is not itself subject to the state tax, it would have to be multiplied by $1 /(1-t)$ to convert it into dollars equivalent in terms of buying power to the rest of the taxpayer's incoine, which is subject to the state tax. Also, one must account for the fact that revenue and thus public benefits will be lower with a federal income tax in place.)

57 Indeed, if taxes are independent of incoine, the treatment that would result in taxes not affecting relative well-being anong regions entails permitting a deduction. See Kaplow, supra note 53, at 29-31. This result follows from the same logic indicating that an inclusion of $T$ is appropriate if benefits are the same for all levels of income. Of course, allowing all a deduction of $\mathrm{T}$ and requiring all to include $\mathrm{T}$ would be equivalent to simply disallowing the deduction.

58 The previous illustration showed that allowing a deduction for the cost-of-living difference, which here is $T_{i}$, would be too large. If one subtracts $T$ from this deduction $\left(T_{i}-T\right)$, it follows that the resulting deduction would be too large compared to the combined effect of a cost-of-living adjustment and inclusion of the benefit $T$ in income (because, after all, including $\mathrm{T}$ is equivalent to subtracting $\mathrm{T}$ from any deductions that are taken).

It can be shown that if beneflts or taxes vary with income but not in a strictly proportional manner, the adjustments that preserve relative well-being would be more coinplicated, but it still would generally be true that the benchinark deduction would be too large according to this approach. See Kaplow, supra note 53, at 31-32. 
tion for the federal income tax because consuinption (the base of the $\operatorname{tax}$ ) is financed with after-federal-income-tax dollars. ${ }^{59}$

It is worth noting that all of this discussion is premised on an assumption implicit in conventional ability-to-pay analysis of deductibility: the state and local tax regime is taken as given. If, instead, state and local taxes will be adjusted in light of federal taxes-including the rules regarding deductibility-the proper analysis would differ. For example, if state and local governments were to adjust taxes in response to federal rule changes in a inanner that preserved the after-tax distribution of incoine, ability-to-pay questions would become moot, and the matter would concern the appropriateness of the resulting distribution of revenue available to state and local governments. 60

Much of the analysis in this Article, including the present discussion of cost-of-living differences, takes for granted that adjustinents that preserve relative well-being across jurisdictions are desirable. Although such equitable treatment often may be appropriate, ${ }^{61}$ it need not be in the present context. From a

${ }^{59}$ That is, the typical state income tax applies to before-federal-income-tax dollars, assuming that the state tax does not allow a deduction for the federal tax. (For those state income taxes that do allow a deduction-thereby automatically changing when the federal income tax changes-the previous discussion of the sales tax would be applicable.) Observe that in the simple case of a proportional state income tax at rate $t_{s}$ and a federal income tax at rate $t_{f}$, deductibility of the federal tax-in the amount $t_{f} Y$, where $Y$ is income-on the state tax is worth $t_{s} t_{f} Y$, which is exactly what deduction of state income tax-in the amount of $t_{s} Y$-on the federal tax at rate $t_{f}$ is worth.

60 See infra note 62 and Parts IV.VI. For the purposes of examining this issue concerning available state and local revenue, one might wish to take as a benchmark the distribution that would exist in the absence of the federal income tax. The preceding analysis in the text would then be applicable (for then the assumption of ignoring reactions to changes in the federal income tax would be an appropriate one), as well as the discussion to follow concerning the possibility that tax differences might be offset by amenity differences.

61. The criterion involves comparing welfare levels among individuals, which may be appropriate if the applicable redistributive norm were based on the egalitarian approach associated with John Rawls, A Theory of Justice (1971). For a social choice theory literature survey that compares distributive theories, see Amartya Sen, On Weights and Measures: Informational Constraints in Social Welfare Analysis, 45 Econometrica 1539 (1977). The utilitarian approach is developed and defended formally in John C. Harsanyi, Rational Behavior and Bargaining Equilibrium in Games and Social Situations ch. 4 (1977); see also Louis Kaplow, A Fundamental Objection to Tax Equity Norms: A Call for Utilitarianism, 48 Nat'1 Tax J. 497 (1995) (defending a utilitarian approach to tax policy). A major difference between the utilitarian approach and the Rawlsian approach is that the utilitarian approach is concerned with equating individuals' narginal utilities rather than total utilities. See generally Dennis 
national perspective, different tax burdens may result in a more favorable distribution or might allow the federal government to conserve revenue; pursuing such subtleties is beyond the scope of the present investigation. 62

Another problem with any sort of cost-of-living adjustment involves interregional differences in amenities. For example, if $A$ is a particularly desirable place to live (low crime, good climate, recreational facilities), it will attract residents, which will bid up land rents and contribute to a higher cost of living. Costof-living adjustments miglit then lead to a less reliable indication of relative well-being. ${ }^{63}$ Similarly, it may be that some jurisdictions can impose higher taxes on wealthy residents witlout providing public services to them and nonetlieless avoid excessive out-migration precisely because the jurisdiction has amenities of the sort preferred by ligh-inconie residents. In that case, failing to allow a deduction for their ligher taxes would offset the failure to tax the benefits they receive froin the better amenities. ${ }^{64}$

This qualification to any argunient for adjustments is related to the view noted in Subsection 1 that one should not impute the value of costs and benefits but rather infer value fron individuals' actual decisions. If high-wage workers stay in New York

C. Mueller, Public Choice II chs. 21, 22 (1989) (introducing and summarizing critiques of both formulations); Bankman \& Griffith, supra note 44 (applying Rawlsian and utilitarian formulations of distributive justice to the income tax).

Designing a tax to preserve relative welfare levels across regions also has efficiency implications with regard to the interregional allocation of production. See Kaplow, supra note 53, at 10-11. Compare Oakland's discussion of why fiscal equalization may be inefficient because, by compensating for real cost differences among localities, locational incentives will be distorted. Oakland, supra note 36, at 203-04.

62 These ideas are explored in Kaplow, supra note 53, at 12-17, in the context of real cost-of-living differences. A contrast with the present context is that here, savings might arise not from economizing on real resources but from reducing revenues of some state and local governments. Assessing such effects would depend in part on the desirability of these governments pursuing policies that provide benefits to their residents that differ from the taxes they pay and on whether jurisdictions that are able to impose additional taxes on wealthy inhabitants are entitled to that revenue for local use rather than having the revenue taxed and distributed by the federal government. See infra Parts IV-VI.

${ }^{63}$ See Jennifer Roback, Wages, Rents, and Amenities: Differences Among Workers and Regions, 26 Econ. Inquiry 23 (1988).

${ }^{64}$ In the absence of higher taxes, one might expect the value of the amenities to lead to higher land prices; paying more rent would be viewed as nondeductible consumption (although homeowners' consuinption would implicitly be deductible because imputed rental income is untaxed). See also infra note 65. 
City despite its high tax rates, it must be that there are sufficient offsetting attractions to keep them there, so one should not presume that their well-being is lower than that of individuals who earn the same wage elsewhere and pay lower state and local taxes. 65

In principle, it may be possible to determine real cost-of-living differences (including the effects of state and local taxes) by comparing wages paid in different jurisdictions for the same occupation. If wages are higher in A than in B, this would tend to reflect differences im living costs net of amemity differences. ${ }^{66}$ Such information would permit cost-of-living adjustments without separately identifying the component that was due to tax

65 Similar reasoning is applicable to Zelinsky's argument, discussed supra note 27, that some deductibility may be justified because the tax revenue should be seen not as funding benefits but as restoring a deficit, as when more funds are spent on police because crime is unusually high. Individuals will choose to live in a high-crime (or an average-crime but high-tax) area only if there are offsetting benefits, such as other, positive amenities, lower rents, and so on; that is, the overall package must be sufficiently attractive. From this reference point, spending more to improve one component, even if that component is initially below average, should be seen as producing a benefit.

One complication is untaxed imputed income. If one amenity offsets a deficit in another, or if low rent offsets a disamenity, there is symmetry with respect to the tax system. If, instead, higher wages offset disamenities, the result is different because the lower amenity reduces untaxed imputed income whereas the higher wage raises taxable income. (This problem is no different than that which arises without regard to the problem of state and local taxes: when coal miners are paid more than clerks who work in pleasant surroundings, the compensating wage differential paid to the former is taxed, but the benefit of more pleasant surroundings available to the latter is not.) This argument suggests that any argument for adjustments on account of state and local taxes would need to be premised upon the offsetting locational benefit being higher wages rather than lower living costs or other, nonpecuniary benefits; moreover, the argument for an adjustment depends on the higher crime leading to higher wages, without regard to whether the jurisdiction also levies additional taxes to combat crime.

66 Note that the differences could reflect entirely psychic costs. For example, if the costs of goods and services were the same in two regions but $A$ was a less pleasant place to live (and this difference was not reflected fully in lower land prices in A), wages in $\mathrm{A}$ might be higher. This wage difference might then be deemed a real "cost-of-living" difference. Although differences in psychic benefits of work are usually ignored, they do affect well-being, and in the case just described, they may be measurable as a practical matter. More precisely, the total differences in economic and psychic costs may be measurable, using the wage differential, and in theory there may be no reason to distinguish the two. For a discussion of wage differentials as measuring the value of differences in amenities, see Sherwin Rosen, Wage-based Indexes of Urban Quality of Life, in Current Issues in Urban Economics 542 (Peter Mieszkowski \& Malılon Straszheim eds., 1979). 
differences rather than other cost differences. Available evidence does not, however, provide confidence in the feasibility of such an endeavor. ${ }^{67}$

The federal income tax does not provide regional cost-of-hiving adjustments. It seems plausible that real cost-of-living differences are inore sigmificant than tax differences (that do not reflect payment for higher benefits available in a region). In addition, Parts II and III suggest that tax differences may be far more difficult to identify and ineasure, particularly in liglit of difficulties in tracing benefits and determining the incidence of state and local taxes. Thus, one miglit be tempted to argue by analogy that there should be no deductibility or other adjustments for state and local taxes. But the failure to provide cost-of-living adjustments has not been carefully defended, so the issue can hardly be resolved so readily.

\section{INCIDENCE: BENEFIT VIEW VERSUS NEW VIEW}

Public finance economists' analysis of state and local taxing and spending is concerned with the questions of how the level and type of taxes and expenditures are determined and how these public sector activities influence private behavior. The problems are interconnected: the inobility of capital and labor will influence taxing and spending decisions and these decisions will influence inobility. Although the analysis has not been designed for the purpose of illuminating the question of deductibility, both equity and efficiency aspects of the problem can be assessed by reference to this work on the local public sector. ${ }^{68}$

Sections A and B examine the assumptions and implications for deductibility of the benefit view and so-called new view of the property tax. ${ }^{69}$ Section $C$ addresses how similar analysis is relevant to sales and income taxes. (Although the property tax is used primarily by local governments, whereas sales and in-

67 See Kaplow, supra note 53, at 21-23.

6 Standard references are cited supra note 9. Recitations in Sections A and B of basic points from this literature omit what would otherwise be repetitive citations. In addition, most of the refinements in this literature must be ignored in a project such as this for ease of exposition; many are surveyed in the standard references cited previously.

${ }^{69}$ See also supra note 14 (discussing old view). 
come taxes are used primarily by state governments, the principles do not depend directly on the level of government. Nonetheless, the results may.differ due to differences in the amount of mobility and because of a hierarchical relationship: mobility is less between states than between localities, ${ }^{70}$ and states set rules for localities and may engage in fiscal equalization among localities.)

\section{A. Benefit View}

\section{The Simple Benefit View}

The benefit view describes a scenario in which individuals choose among competing jurisdictions much as they choose among competitive suppliers of goods and services. In the perfectly competitive scenario, associated with Tiebout, ${ }^{71}$ there is a precise match between preferences for public services and locations. Thus, all residents of a given jurisdiction will have identical preferences and pay identical taxes. In the simplest models, these would be head taxes (also called lump-sum taxes or poll taxes). The tax would be an entrance fee for access to the jurisdiction's services, analogous to dues for membership in a private club. ${ }^{72}$

In this scenario, taxes will equal benefits in all jurisdictions, so the first benchmark case in Part I would apply, and no deductibility would seein appropriate. Of course, the stated assumptions hardly hold perfectly. But one might believe that they are approximately true in the long run. ${ }^{73}$ As with private goods, the competitive story only requires comparison shopping by a sufficient portion of individuals to discipline the market.74

${ }^{70}$ See, e.g., Oates, supra note 9, at 139.

71 Charles M. Tiebout, A Pure Theory of Local Expenditures, 65 J. Pol. Econ. 416 (1956).

72 For an introductory discussion of the economic theory of clubs and its relationship to Tiebout's voting-with-the-feet analysis, see Dennis C. Mueller, supra note 61 , ch. 9.

73 For a survey of some of the evidence bearing on mobility and the availability of community choice, see id. at 168-70. For recent empirical evidence, see Thomas J. Nechyba, Fiscal Federalism and Local Public Finance: A General Equilibrium Approach with Voting, 1994 Proc. of the Nat'l Tax Ass'n 136, 140 (1995).

${ }^{74}$ See Alan Schwartz \& Louis Wilde, Intervening in Markets on the Basis of Imperfect Information: A Legal and Economic Analysis, 127 U. Pa. L. Rev. 630 (1979). 
Also, one might imagine that preferences for levels of public services tend to be rather similar among those of the same income, and in many areas there is substantial segregation by income among local jurisdictions. ${ }^{75}$

In addition, each jurisdiction chooses the taxes and benefits it provides, so taxes and benefits will tend to reflect inlrabitants' preferences. For example, it may be tliat, because of the limited number of jurisdictions im an area or because of preferences for heterogeneity im living arrangements, residents' incomes vary. If head taxes are used to finance equal benefits for everyone, this would not raise a problem. If property taxes are imposed, as is usually the case, wealthier residents will pay higher taxes. ${ }^{76}$

${ }^{75}$ For references to empirical evidence on sorting, see Keith Dowding, Peter John \& Stephen Biggs, Tiebout: A Survey of the Empirical Literature, 31 Urb. Stud. 767 (1994), and Inman \& Rubinfeld, supra note 9, at 1669 n.20.

${ }^{76}$ If property taxes are not required, analysis of the new view, see infra Section B, implies that head taxes would be chosen (assuming that uniform benefits are to be financed). See Mieszkowski \& Zodrow, supra note 9, at 1111-13; George R. Zodrow \& Peter Mieszkowski, The New View of the Property Tax: A Reformulation, 16 Regional Sci. \& Urb. Econ. 309, 312-13 (1986); see also J. Vernon Henderson, Will Homeowners Impose Property Taxes?, 25 Reg. Sci. \& Urb. Econ. 153 (1995) (arguing that in properly specified Tiebout model, homeowner-residents would not choose property taxes); Russel R. Krelove, The Persistence and Inefficiency of Property Tax Finance of Local Public Expenditures, 51 J. Pub. Econ. 415 (1993) (stating that if direct taxes on residents are unavailable, property taxes rather than land taxes would be used).

This raises the interesting question of why localities use property taxes rather than head taxes. One explanation is that states might require the use of local property taxes because political forces at the state level of the sort examined in Part IV favor greater redistribution. But the intrajurisdictional redistribution induced by property taxation is a curious result to be pursued by a state. For example, the middle-class who live in wealthy jurisdictions benefit and the middle-class who live in poor jurisdictions lose. Also, the extent of redistribution is undermined by mobility, which is greater for local jurisdictions within the state than for the state as a whole. Of course, the property tax is deductible whereas some alternatives would not be. See I.R.C. $\$ 164$ (a) (1994). (And the property tax is closer to a head tax than sales or income taxes, especially for localities with importing-exporting issues. State-level property taxes could be used instead, but states may be reluctant on administrative grounds to employ such taxes because each locality would have an incentive to under-assess and state administered assessment may be more difficult.) But prior to 1964, all state and local taxes were deductible, so deductibility seems a poor historical explanation for selection of the property tax. There are some enforcement problems with head taxes (as when individuals purport to live elsewhere when they are actually living with friends or relatives in a high-tax, high-benefit jurisdiction), whereas property is easy to identify. It is not clear, however, that enforcement is a significant impediment. Some expensive benefits-notably, public education-can readily be limited to children of adult residents who have paid their head tax. Also, taxes could be imposed 
But the political process or constraints imposed by the potential out-migration of the wealthy and in-migration of the poor may lead the jurisdiction to provide a mix of public goods and services that is more valuable to the wealthy.77

on residences independent of their value. Alternatively, greater reliance on user charges, although it involves some additional administrative cost, would often be feasible. Henderson suggests that homeowner-residents would not prefer property taxes and argues that the substantial decline in the use of property taxes since 1950 might be explained by the concurrent increase in home ownership over the subsequent time period.

Of some relevance is the unsuccessful recent experience of Britain in substituting a poll tax (head tax) for a property tax to finance local government. Peter Smith, Lessons from the British Poll Tax Disaster, 44 Nat'l Tax J. 421 (1991), analyzes reasons for this failure; it appears, however, that many are not obviously inherent and some refiect that the property tax was already in place. See also Robert Bowles \& Philip Jones, Nonpayment of Poll Tax: An Exploratory Analysis of Tax Resistance, 13 Int'l Rev. L. \& Econ. 445 (1993) (examining factors influencing nonpayment of the poll tax). The British poll tax was subject to inass evasion, see Timothy Besley, Ian Preston, and Michael Ridge, Fiscal Anarchy in the U.K.: Modeling Poll Tax Noncompliance (National Bureau of Economic Research Working Paper No. 4498, 1993), but this reflects at least in part some of the peculiar circumstances described by Sinith and the fact that the government at the time did not impose sanctions for nonpayment (and this was well known). Finally, if the incidence of local benefits more closely matched the incidence of the long-existing property taxes rather than that of the new poll tax, see infra note 77, the resulting disruption to the economic and political equilibrium might have induced opposition.

Fischel argues that any requirement to use a property tax could be repealed (for example, state constitutions are often amended); thus, one should infer that property taxes are relatively efficient because this has not happened. See William A. Fischel, Property Taxation and the Tiebout Model: Evidence for the Benefit View from Zoning and Voting, $30 \mathrm{~J}$. Econ. Lit. 171, 175 (1992). It has been suggested that property taxes may be more attractive than head taxes because of the better incentives provided to local governments under the former. See Edward L. Glaeser, The Incentive Effects of Property Taxes on Local Governments (National Bureau of Economic Research Working Paper No. 4987, 1995). Relatedly, land taxes-or property taxes, because they apply to land value as well-allow local governinents to extract the value of local amenities, some of which are produced using the tax revenues. See also infra notes 77,101 and 102 (indicating that, in practice, the benefits financed by property taxes favor those who pay more and property tax payments are adjusted to reflect benefits received).

$n$ According to Rubinfeld, available evidence indicates that local taxes are somewhat regressive and spending somewhat pro-rich, a pattern in which taxes paid inay be close to the value of public goods and services received. See Rubinfeld, supra note 9, at 630-31; see also W. Irwin Gillespie, Effect of Public Expenditures on the Distribution of Income, in Essays in Fiscal Federalism 122 (Richard A. Musgrave ed., 1965) (finding some redistribution in favor of the lowest-income groups and an approximately neutral net effect-taxes equal to public benefits-at higher incoine levels for state and local taxes and some expenditures); Inman \& Rubinfeld, supra note 9 (arguing that legal strategies designed to increase redistribution at the local level will have 
This competitive scenario is vulnerable to criticism. ${ }^{78}$ First, the assumptions are questionable. ${ }^{79}$ Jurisdictional choice is limited, due to economies of scale or historical accident. ${ }^{80}$ Mobility - particularly out of cities or between states-may be constrained. ${ }^{81}$ Political processes that determine taxes and spending do not perfectly reflect residents' wishes, which are not well-defined in the presence of heterogeneity. Second, property taxes rather than user charges or head taxes are commonly used in local finance. Although more expensive property may benefit inore from some government services, many doubt that benefits vary to the extent of tax differences. It is still possible, however, that the benefit view is correct, as the next Subsection explains.

\section{Perfect Capitalization}

The power of the perfect capitalization idea ${ }^{82}$ can be illustrated using the assumptions of the second benchmark case, in which all residents receive equal benefits from the public sector, whereas tax payments differ. In particular, with a property tax, those living in more expensive homes pay nnore tax. It might appear, therefore, that an adjustment (deduction for high-tax and inclusion for low-tax residents) is appropriate.

limited success); infra note 102. One study of property tax incidence in Great Britain before implementation of poll taxes (see supra note 76) suggests that the incidence of benefits was closer to the incidence of the property tax than that of the poll tax. See Glen Bramley, Julian LeGrand \& William Low, How Far Is the Poll Tax a 'Community Charge'? The Implications of Service Usage Evidence, 17 Pol'y \& Pol. 187 (1989). (Given the many problems the study has in establishing incidence, its result should be viewed as merely suggestive.) See also infra Subsection B.3 and note 101 .

With regard to demographic redistribution, see supra Subsection I.B.4, a convergence of taxes and benefits may be approximated by bundling increased expenditures on schools (benefiting younger families) with increased expenditures on programs for the elderly.

${ }^{78}$ See generally Dowding et al., supra note 75 (surveying empirical literature on assumptions and implications of Tiebout's model).

${ }^{79}$ See, e.g., Billman \& Cunmingham, supra note 6, at 1113.

$\$$ See, e.g., Bruce W. Hamilton, A Review: Is the Property Tax a Benefit Tax?, in Zodrow, supra note 9 , at 85 ,

81 See, e.g., Oates, supra note 9, at 139.

8 See, e.g., Bruce W. Hamilton, Capitalization of Intrajurisdictional Differences in Local Tax Prices, 66 Am. Econ. Rev. 743 (1976); Mieszkowski \& Zodrow, supra note 9, at $1100,1107-1110$. 
This argument, however, ignores the effect of the property tax on housing values. If the quantity of housing is fixed, one would expect property values fully to adjust on account of the property tax. Thus, if hiving in an expensive home required that one pay an additional $\$ 10,000$ in property taxes (measured in present value) above the value of any local public benefits, the value of that home to a prospective buyer would be $\$ 10,000$ less on that account. Housing prices would adjust to reflect this difference. Similarly, buyers of inexpensive homes in a jurisdiction would face the prospect of receiving benefits at a charge less than their worth; hence, such homes would be more valuable to this extent, and the price of such homes would be higher. As a result, the total housing costs of individuals in each group would be unaffected in equilibrium. Those who choose to purchase expensive hoines pay more in taxes but have lower imputed rental costs; the reverse is true for buyers of less-expensive homes. For renters, the story is similar. Landlords who rent expensive homes would have higher tax costs but lower capital costs; the converse would be true for less-expensive homes. ${ }^{83}$

In sum, if perfect capitalization prevails, property taxes do not measure benefits, but property taxes plus adjustments in the capital cost of housing do equal benefits. Arguably, no deductibility would be appropriate: everyone in the jurisdiction receiving equal benefits bears the same total cost (property taxes plus capital cost adjustments), which just equals the benefits. ${ }^{84}$

83 Although one normally would expect rent to reflect property taxes, when individuals are mobile rents will reflect only the value of public benefits associated with residence. Thus, renters will get what they pay for. Landlords paying taxes in excess of benefits will suffer from a lower return, so their property will be worth less. If the landlord bought the property after the tax was in place, this will be reflected in a lower purchase price, just as with owner-occupiers (whose situation is simply the combination of the effect on landlords and the effect on renters).

84 The perfect capitalization argument focuses on the equilibrium prevailing after property taxes are in effect. Because property taxes have existed for a long period of time and usually are changed only gradually, this perspective may be appropriate. But at the time the property tax is enacted or changed, there will be capital gains and losses to the extent that the event is not entirely anticipated. See generally Louis Kaplow, An Economic Analysis of Legal Transitions, 99 Harv. L. Rev. 509, 515-19 (1986) (discussing transition effects from legal reforms). The tax system takes such gains and losses into account, although imperfectly due to the realization requirement, I.R.C. § 1001(c) (1994), special treatment of capital gains, I.R.C. § 1(h), and forgiveness of capital gains on death, I.R.C. $\S 1014$. For homeowners in particular, there is 
There are, however, two important caveats. First, if there is perfect capitalization, deductibility itself would also be capitalized. (Deductibility would reduce the effective cost of the tax, so the property value adjustments would be less in an offsetting manner.) Therefore, under perfect capitalization, the choice of rule arguably is irrelevant for measuring abihty to pay. ${ }^{85}$

Second, it is not clear that perfect capitalization often describes reality. As will be discussed at greater length in the next Section (on the new view of the property tax), one would expect the amount of capital to adjust in the long run. Thus, if the property tax rate is higher, individuals would choose to build, rebuild, or maintain homes of somewhat lower value. If the capital stock is fully adjustable, the new view prevails, and the preceding analysis is inapplicable.

Communities may, however, attempt to prevent adjustments of the capital stock through zoning and related restrictions. When equal benefits are financed by a property tax, communities will fear that individuals will attempt to secure those benefits cheaply by building low-cost housing or increasing the occupancy of existing housing. To prevent this, existing residents have an incentive to impose minimum lot and square-foot requirements, limits on multiple occupancy, and charges on devel-

also the rollover possibility, I.R.C. $\$ 1034$, and one-time forgiveness, I.R.C. $\$ 121$. Loss limitations may be important for those who own property subject to taxes that exceed benefits. For homeowners, losses are not deductible because they are personal, although there may be de facto deductibility to the extent the loss offsets what would otherwise have been capital gains. In sum, because losses are not deductible and gains will generally not be realized or will be forgiven, the regime applicable to homeowners is approximately one of ignoring capital gains and losses from housing. As a result, providing a property tax deduction-or, more particularly, the sorts of deductions and inclusions described for the second benchmark in Section B-might be seen as an indirect way of accounting for such gains or losses. (For homeowners who sell after a tax change, the sales price will reflect deductibility and thus the price movement will be less, so the tax deduction will mitigate the extent of the capital gain or loss actually borne by the taxpayer in a manner similar to what would result if the gain or loss were instead accounted for directly.) It is not clear, however, what policy would lead one generally to ignore capital gains and losses on homes but to account for them indirectly to the extent they were due to property tax changes but not other factors. See also infra Subsection B.4 (inelastic supply of land under the new view).

${ }^{85}$ For any of the rules concerning deductibility, the caveats in note 84 apply. In addition, in a system with graduated rates, the capitalization of federal income tax effects will be complicated because different market participants will value tax benefits differently. Finally, there would remain efficiency effects. See infra Section VI. 
opers (as in charges for streets and utility connections and requirements to create pubhic parks as part of a project). If such restrictions are perfectly bimding, individuals cannot pay lower property taxes by acquirimg less housing, and perfect capitalization will occur. If not, the analysis of the new view will be more relevant.86

\section{B. New View}

\section{Explanation}

The new view of the property tax emphasizes the mobility of capital and concludes that owners of capital bear the property tax, although differences in property tax rates have effects similar to those of an excise tax..$^{87}$ To illustrate the argument, suppose initially that the return to capital (imterest rate) is $10 \%$. The relevant world consists of two identical towns, neither of which has a property tax. Suppose that one of the towns then enacts a property tax at a rate of $2 \% .{ }^{88}$

${ }^{86}$ See, e.g., Fischel, supra note $76 ;$ Mieszkowski \& Zodrow, supra note 9, at $1112-13,1140$.

87 This view was initially developed by Procter Thompson, The Property Tax and the Rate of Interest, in The American Property Tax 111 (George C.S. Benson, H. McClelland \& P. Thomas eds., 1965), Peter Mieszkowski, The Property Tax: An Excise Tax or a Profits Tax?, 1 J. Pub. Econ. 73 (1972), and Henry J. Aaron, Who Pays the Property Tax? (1975). For an accessible discussion of the literature, see McLure, supra note 14.

88 The analysis considers the case in which one town has a property tax at a given rate and another town has no tax. The analysis is the same-although the magnitudes differ-when both towns have positive taxes, but at different rates. The analysis focuses on differences in property tax rates, abstracting from effects of the average rate. Under the new view-that is, assuming capital mobility-the effect of the average tax rate is to reduce the return to capital to that extent. (In the example in the text, the average rate of $1 \%$-one town's rate is $2 \%$ and the other's is $0 \%$-is reflected in the return to capital falling from $10 \%$ to $9 \%$. See infra Subsection 2.a.)

The example also imphicitly assumes that all capital is housing in the two towns. (Property taxation of business property is addressed in Part III.) The logic of the analysis implies that the average return on all capital, of whatever type and wherever located, would fall. Thus, the town with no tax can be taken as a proxy for the rest of the world in which capital is not subject to the property tax-or in which any taxes are taken as given when the property tax in the first town is introduced. It remains the case that a relatively higher tax burden on capital in the first town will produce an excise effect, requiring in equilibrium a higher gross rent to the extent of the difference. 
The immediate effect of the town's property tax appears to be that the return to residential capital in the town would fall to $8 \%$. But in the long run the amount of capital invested in such a town would fall: investors will prefer the $10 \%$ return in the town with no property tax to the $8 \%$ return in the town with the tax. As capital falls in the town with the tax, rents per unit of capital will rise; similarly, as capital rises in the town without the tax, the return will fall relative to the original return. This process will continue until the rates of return are equal in the two towns-say, at $9 \% .89$

Finally, consider the equilibrium level of rents. If the net return to capital in the town with the property tax is $9 \%$, it must be that rents have risen sufficiently to provide a gross return of $11 \%$, so that after payment of the $2 \%$ property tax the capital owner will net $9 \%$. In the town without the property tax, rents will be sufficient to yield $9 \%$. Thus, gross rental rates-the cost to residents per unit of housing - are higher in the town with the property tax, which is consistent with the reduction in capital in that town.

\section{Appropriate Treatment \\ a. Landlords}

Consider capital owners who are landlords (that is, who are not owner-occupiers). Those who own capital in the town without a property tax now earn $9 \%$ rather than $10 \%$. This reduction in return is already reflected in the gross rents they receive, so these rents will properly reflect gross income. (Thus, even though they bear some of the burden of the property tax in the other town, there is no need for a deduction for the taxes they do not pay directly; their gross rent is lower by an amount that reflects the burden they bear.) Those who own capital in the

${ }^{89}$ This process will take time, but property taxes have existed for decades and unanticipated rate changes tend to be modest. The equilibrium rate of return will depend, among other things, on the amount of capital initially in each town and the elasticity of demand for capital in each town. The analysis to follow does not depend on the particular equilibrium rate of return. Also, if one considered an actual world of many towns (rather than only two, as assumed here) and only a single town implemented a property tax, the average return to capital would fall a very small amount, with virtually the entire amount of the tax being reflected in higher rents. 
town with the $2 \%$ property tax have a net return of $9 \%$ but receive rents sufficient to provide an $11 \%$ gross return. Their income is properly measured by allowing a deduction for the property tax. 90

\section{b. Renters}

As a whole, renters benefit from the property tax: because owners of capital bear the burden of the property tax, the return on capital falls to $9 \%$, so housing becomes cheaper, the capital costing $9 \%$ rather than $10 \% .91$ For those in the town without the property tax, rents fall. Those in the town with the property tax pay higher gross rents, but their town now has the revenue from the property tax. If one assumes that these tax revenues provide residents with benefits that are equal to their costs, then on average renters pay $11 \%$ and receive benefits of $2 \%$, for a net capital cost of $9 \%, 92$

In addition, there is a reallocation of capital that is inefficient: relative to the actual cost of capital, residents in the town with the property tax face a high price and use too little capital, and those in the town without the tax face a low price and use too much capital..$^{93}$ That residents in the town with the tax face a high price is not inconsistent with the fact that, on average, their

90 They bear $1 \%$ (their net return is now $9 \%$ rather than $10 \%$ ), but their gross return has risen $1 \%$ (from $10 \%$ to $11 \%$ ), so a deduction of $2 \%$ (which equals the amount of the property tax paid) provides the correct result.

${ }^{91}$ Owner-occupiers are worse off in their capacity as landlords (capital owners) but are better off as renters. See infra Subsection c.

92 The benefit to renters-in both towns the net rental price is $9 \%$ rather than $10 \%$-is similar to the benefit that arises when the cost of capital falls for reasons unrelated to the property tax.

93 The effect of higher property taxes on average (as distinguished from relatively high rates in a particular jurisdiction) is to increase the price of housing (assuming that housing capital is subject to the tax but other capital is not, see supra note 88), which would result in inefficiently low housing consumption. But if housing is otherwise excessively consumed, perhaps because the income tax excludes imputed rent and corporate capital is taxed more heavily than noncorporate capital, the distortion caused by higher property taxes may be efficiency-enhancing. See, e.g., S. Devarajan, D. Fullerton \& R.A. Musgrave, Estimating the Distribution of Tax Burdens: A Comparison of Different Approaches, 13 J. Pub. Econ. 155, 169-171 (1980). For a discussion of the distinction between the differences in tax rates and the average tax rate for assessing the efficiency consequences of property taxation, see Wildasin, supra note 9 , at 111-13. 
net burden is only $9 \%$ rather than $11 \%$, on account of the $2 \%$ public benefit. Each resident's public benefit is assumed to be independent of the size of her home; 94 hence, by reducing consumption of housing, residents keep the same benefits but reduce their housing costs. The relevant marginal cost of housing is $11 \%$.

Now consider the differential effect among renters in the town with the property tax. Suppose that residents' benefits are independent of their housing consumption. Then, those in large homes implicitly pay taxes in excess of the benefits they receive, and those in small homes bear an implicit tax burden that is less than the benefits they receive. For example, if half the residents live in $\$ 100,000$ houses and half in $\$ 200,000$ houses, the former group pays, through higher rents, $\$ 2,000$ in property taxes, and the latter group pays $\$ 4,000$. Publicly funded benefits per capita are $\$ 3,000$.

This case fits the second benchmark in Part I. If the second benchmark dictates appropriate treatment, ${ }^{95}$ it suggests that those who rent large houses sliould have a $\$ 1,000$ deduction and those who rent small liouses should liave a $\$ 1,000$ inclusion. This is the result given by the formula which permits a deduction of $T_{i}-T$ : here, $T_{i}$ equals $\$ 4,000$ for those in large lomes and $\$ 2,000$ for those in small liomes; $T$ equals $\$ 3,000$. These deductions and imclusions apply to renters despite the fact that they do not pay the tax directly, because they implicitly pay the tax through higher rents. Indeed, the effects would be no different if the property tax were imposed directly on renters..$^{96}$

94 To the extent that the benefit is not independent of the amount of capital invested but rather is, say, increasing with the level of capital, the property tax would be a benefits tax, and the return to capital would not decrease on this account. Then, the benefit view rather than the new view would be partially applicable.

${ }_{95}$ The treatment given by the second benchmark is subject to all of the qualifications noted in Part I. For example, if benefits are not equal but rather are a function of property values, any adjustment must be modified accordingly. Moreover, the discussion in Section I.C questions whether even the limited deductions (and inclusions) implied by the second benchmark are appropriate, even without regard to factual qualifications.

${ }_{96}$ New York State amended its property tax law so that the tax was nominally on renters rather than landlords, but the IRS did not permit renters to deduct the tax, a result it attempted to justify by arguing that the new law did not in fact transfer the obligation from owners to renters. Rev. Rul. 79-180, 1979-1 C.B. 95. The fact that current law bases deductibility on who is formally responsible for the tax payments 
(Owners' gross rents would be lower by the amount of the tax but their net return on capital would be the same; renters would pay less rent but more tax, yielding the same total outlay.)

To verify this result - which may seem counterintuitive-compare, for example, renters of $\$ 200,000$ homes in the town with the tax to renters of $\$ 200,000$ homes in the town without the tax. The former pay higher rent in the amount of the tax, $\$ 4,000$. (Recall that this inust be true in equitibrium, in which the net return to capital is equal in both towns.) The former also receive benefits of $\$ 3,000$. In total, therefore, renters in the town with the tax are worse off by $\$ 1,000$, which explains the $\$ 1,000$ deduction inplied by the formula for the second benchmark case.

\section{c. Owner-Occupiers}

Consider capital owners who are owner-occupiers. In their capacity as owners (renting to themselves), owner-occupiers have the same $2 \%$ expense as true landlords (nonowner-occupiers) $-\$ 2,000$ for a $\$ 100,000$ house. But they also receive imputed rent sufficient to provide an $11 \%$ gross return $-\$ 11,000-$ which is not taxed. Otherwise similarly situated owner-occupiers in the town without the property tax pay no property tax but receive imputed rent sufficient to provide only a $9 \%$ return - $\$ 9000$. Thus, owner-occupiers who pay property tax- $\$ 2,000$ - have higher imputed gross rent in the same amount- $\$ 11,000$ rather than $\$ 9,000$. As a result, it nay be argued that no deduction should be provided to those in the town with the property tax if owner-occupiers of equal-cost houses are to have the same amount of imputed income excluded. 97

even in settings where hittle of economic substance turns on the formal distinction suggests that the existing rule is misguided. This shortcoming of the existing legal distinction, however, does not indicate whether the deduction should be denied to owners, extended to renters, or otherwise adjusted.

${ }^{97}$ As owners of capital, owner-occupiers receive a net return of $9 \%$ regardless of the town in which they live. In principle such imputed income should be taxable though in practice it is not. But, as long as no property tax deduction is allowed, the failure to tax imputed income does not differentiate owner-occupiers in the two towns: excluded net income is $9 \%$ in either case.

Although not undertaking a complete analysis, many commentators have suggested 
This argument is incomplete because it focuses on owner-occupiers solely in their role as owners of capital (landlords). As occupiers of their homes, their situation is like that of renters. If they live in a town with a $2 \%$ property tax, they pay more rent and receive public benefits. As a whole, therefore, owner-occupiers in the town with the property tax are worse off than those in the town without the tax if they hive in an expensive house and better off if they live in an mexpensive house. A deduction (or inclusion) given by $T_{i}-T$ would measure this effect as in the case of renters.

To summarize, imputing rent eliminates what may otherwise seem to be basis for deduction by the recipient-owner, and imputing the property tax payment creates an argument for adjust-

that the failure to tax imputed rental income from housing is a reason for disallowing deduction of the property tax; relatedly, it is suggested, often implicitly, that a deduction may be proper if imputed rent were taxed. See, e.g., Bradford \& the U.S. Treasury Tax Policy Staff, supra note 1, at 84; Richard Goode, The Individual Income Tax 171 (rev. ed. 1976); Vickrey, supra note 25, at 22; William F. Hellmuth, Homeowner Preferences, in Comprehensive Income Taxation, supra note 23, at 163, 179-81; Richard Pomp, Mortgage Interest and Property Tax Deduction: A Tax Expenditure Analysis, 1 Can. Tax'n 23, 24-25 (Fall 1979). The discussion in the text supports this suggestion because differences in property tax payments will correspond to differences in imputed income that are excluded from the tax base. The argument in the text to follow, however, indicates that such reasoning is incomplete because homeowners are also occupiers.

An analogy to the problem of excluding imputed rent from housing is suggested by Hulten and Schwab's observation that the imputed income from the public capital stock also is not taxed. See Hulten \& Schwab, supra note 20. In this respect, the tax system favors public rather than private sector activity as long as the public sector owns rather than rents capital. Note that this favoritism is independent of the difference between the way the income tax treats homeowners and renters. Hulten and Schwab argue that neutrality in a simple Tiebout model-in which property taxes are benefits taxes-requires no deduction of the property tax, taxation of imputed income from public capital, and taxation of the interest on government bonds. Id.; see Paul N. Courant \& Daniel L. Rubinfeld, Tax Reform: Implications for the State-Local Public Sector, 1 J. Econ. Persp. 87, $97-98$ (Summer 1987); Roger H. Gordon \& Gilbert E. Metcalf, Do Tax-Exempt Bonds Really Subsidize Municipal Capital?, 44 Nat'l Tax J. 71 (1991); Roger H. Gordon \& Joel Slemrod, A General Equilibrium Simulation Study of Subsidies to Municipal Expenditures, 38 J. Fin. 585 (1983) (showing that elimination of the property tax deduction increases efficiency substantially-main distortions are in housing and the local public sector, and efficiency gains from elimination are large enough that even wealthy homeowners gain; elimination of mumicipal bond interest exemption does much less, because municipalities would shift to deductible property tax financing). Helen F. Ladd, Federal Aid to State and Local Governments, in Federal Budget Policy in the 1980s, at 165, 197-201 (Gregory B. Mills \& John L. Palmer eds., 1984). 
ment by the payor-occupier. This perspective suggests that any argument for deducting taxes, to measure properly the extent to which benefits may not equal tax payments, should focus on the homeowner as occupier-renter and resident-rather than as an owner of capital.

For all renters, imputed and actual, there remains the question whether any adjustment should be made under the circumstances described here. That is, does the treatment suggested for the second benchmark follow from its assumptions? The focus here on renters-consumers of housing-suggests a problem with the argument of the sort described in Section I.C. For the same public goods and services, some consumers (those who choose more expensive homes) are paying a price higher than that paid by other consumers (those who choose less expensive homes). The imcome tax does not ordinarily make adjustments when some consumers get better deals than others-for example, when someone buys a microwave oven on sale or at a less expensive store or when beaches are free in some places but subject to fees in others.98 Relatedly, the largest component of most individuals' cost of living, housing costs, differs significantly across jurisdictions, but, as previously noted, the income tax does not adjust for cost-of-living differences.

\section{Relationship between Taxes and Benefits under the New View}

The discussion in Subsection 2 takes as given that tax payments and the value of benefits received may systematically differ under the new view. But this need not be the case. Some public benefits directly concern residential property. Others may be positively correlated with income, ${ }^{99}$ wlich im turn is correlated with housing expenditures. ${ }^{100}$ Mobility may create pressure for public benefits to be structured in a manner tliat matches the

98 See, e.g., Klein, supra note 50, at 884; J.B. McCombs, Refining the Itemized Deduction for Home Property Tax Payments, 44 Vand. L. Rev. 317, $322-23$ (1991).

99 This may be due in part to income effects: identical goods and services may have a higher monetary value to those with more income. See supra note 33.

100 For evidence on the positive correlation between spending on housing and income, see Stephen K. Mayo, Theory and Estimation in the Economics of Housing Demand, 10 J. Urb. Econ. 95 (1981). 
distribution of different residents' tax payments. ${ }^{101}$ In addition, tax obligations may be modified to approximate benefits more closely. ${ }^{102}$ Thus, the new view does not in itself imply that the second benchmark rather than the first is applicable.

This qualification may appear confusing, for it might seem that, if benefits equaled taxes, the benefit view of the property tax rather than the new view would be applicable. But the new view of the property tax is not directly addressed to whether taxes equal benefits. Instead, it concerns whether the incidence of the tax is on capital, a related but different question. ${ }^{103}$ As Subsection A.2 explains, the applicability of the benefit view of the property tax-the perfect capitalization version in particular-depends on whether zoning and other restrictions prevent capital from adjusting to changes in the rate of return caused by the property tax. If restrictions are binding, capital does not adjust, so the property tax is capitalized into housing prices. Those who pay more taxes relative to public benefits pay less for hoines in a corresponding amount. The net effect is that taxes plus housing cost adjustinents equal benefits. In sum, under the benefit view, it is necessarily true that there will not be differences in well-being that arise froin discrepancies between taxes paid and benefits received.

If capital can adjust-as posited under the new view-Subsection 1 explains how net rates of return will be equalized across jurisdictions. Those who buy expensive lomes will not benefit from a lower cost of capital; gross rents will be higher to the extent of the property tax. Thus, individuals who wisl to buy expensive homes in a jurisdiction will bear the burden of the

101 See supra note 77; Mieszkowski \& Zodrow, supra note 9, at 1099-1100, 1111-12.

102 See, e.g., Fischel, supra note 76, at 176 (noting, for example, that owners of farmland and other open spaces, as well as elderly taxpayers-who do not use schools-often have reduced tax burdens); Dong Hoon Chun \& Peter Linneman, An Empirical Analysis of the Determinants of Intrajurisdictional Property Tax Payment Inequities, $18 \mathrm{~J}$. Urb. Econ. 90 (1985) (finding negative relationship between house value and effective tax rates); Inman \& Rubinfeld, supra note 9, at 1680 (stating that in central cities, high-income residential properties are assessed at a lower percentage of true market value).

${ }^{103}$ See, e.g., John Yinger, Howard S. Bloom, Axel Borsch-Supan, \& Helen F. Ladd, Property Taxes and House Values 134 (1988) ("Even with full capitalization, the property tax rate in the reference jurisdiction affects the 'before-tax' price of housing services and therefore introduces a tax wedge into the housing market."). 
high property tax on such homes even if public goods and services do not provide high levels of benefits. Thus, the central force emphasized in the new view - the mobility of capital-does not guarantee that taxes will equal benefits. Neither does it guarantee inequality: choice of location and consequent pressures on taxes and public benefits may result in an approximate equalization of taxes paid and benefits received, even if buying a marginally larger home would increase one's tax payments without increasing benefits. ${ }^{104}$

\section{Land versus Structures}

As just explained, the new view is grounded in the assumption that, at least in the long run, capital is mobile. With regard to housing, the idea is that decisions about the size and splendor of hoines and apartments to be built as well as decisions about maintenance and renovation will reflect the cost of capital, which includes the property tax. Even in the long run, however, in many local jurisdictions the supply of land will be rather inelastic. ${ }^{105}$ When such land is subject to a property tax that does not finance benefits of equal value, the differential will be capitalized mto land values in the manner outlined in Subsection A.2 (describing the perfect capitalization version of the benefit view). ${ }^{106}$ Indeed, as a first approximation it may be that the benefit view is applicable to the property tax on land and the new view to the property tax on structures. Thus, when there is capitalization, the effects will be borne by the landowners (whe-

${ }^{104}$ It should be emphasized that the distortion of capital markets that is the focus of the new view depends upon the marginal effect whereas whether taxes equal benefits can be viewed as depending upon an average effect. To illustrate, suppose that the value of local benefits tends to increase with income at approximately the same rate as the consumption of housing increases with income. Then, a tax on housing will result in approximate equality between taxes paid and benefits received. As long as the benefits do not accrue as a consequence of housing itself, however, residents have an incentive to buy marginally cheaper homes because this would reduce tax obligations without reducing the value of benefits received.

105 The supply of land is probably more elastic than one might initially suspect. Zoning changes may affect land available for residential use. At the outer fringe of urban areas, agricultural or other undeveloped land may be converted to residential use if the value in that use rises. If residential land is less valuable due to property taxation, there will be less conversion as populations grow.

${ }^{106}$ See, e.g., Dick Netzer, Economics of the Property Tax 35 (1966). 
ther owner-occupiers or landlords) at the time an unanticipated change goes into effect, ${ }^{107}$ whereas in the absence of capitalization the property tax will affect the return on capital and rents (imputed or explicit) over time..$^{108}$

\section{Evidence on the New View}

An important fact cited im support of the new view is that zoning and other constraints do not seein to be binding. If most homes in a community exceed the relevant minimum standards, it is suggested that the regulations do not restrict the exit of capital, and the resulting equilibriuin therefore must have the characteristics of the new view. ${ }^{109}$ Other restraints may, however, exist that make zoning binding despite this observation. ${ }^{110}$ Although there is enipirical evidence concerning how property values are affected by the property tax, ${ }^{111}$ it is difficult to infer whether the benefit view or new view is valid.112 Evidence on rental rates, ${ }^{113}$ as well as evidence regarding the relationship

107 See supra note 84 (discussing tax system's treatment of capital gains and losses due to property tax capitalization).

108 See, e.g., Yinger et al., supra note 103, at 123, 135-36, 141-43.

109 See Mieszkowski \& Zodrow, supra note 9, at 1112-13, 1140.

110 See Fischel, supra note 76.

111 See, e.g., Dowding et al., supra note 75, at 775-79 (survey of literature on capitalization); Hamilton, supra note 80 , at 90 (noting evidence of nearly complete capitalization and inferring support for the benefit view). But see Yinger et al., supra note 103 , ch. 1 (finding incomplete capitalization, but indicating that this may be due to anticipation that assessment differences may be temporary). See also id. ch. 2 (surveying studies and suggesting that capitalization may be less than many indicate due to studies' use of too high a discount rate to convert annual tax payments into present value).

${ }^{112}$ See, e.g., Mieszkowski \& Zodrow, supra note 9, at 1127-31; Wassmer, supra note 9 , at $137-40$.

${ }^{113}$ See Robert J. Carroll \& John Yinger, Is the Property Tax a Benefit Tax? The Case of Rental Housing, 47 Nat'l Tax J. 295 (1994). They find that residential landlords in the Boston area shift little of the property tax to tenants. On this basis, they claim that taxes do not match benefits. Such evidence is also in tension with the new view because it suggests that capital is immobile. Arguably, their evidence suggests that measured tax differences do not correspond to benefits, with the result that the cost of tax differences must be capitalized into the price of land (as inplied by the perfect capitalization version of the benefit view). A partially contrasting result is given by John F. McDonald, Incidence of the Property Tax on Commercial Real Estate: The Case of Downtown Chicago, 46 Nat'l Tax J. 109 (1993), who finds that $45 \%$ of property tax differences across buildings were shifted to tenants. But see Joyce Y. Mann, The Incidence of Differential Commercial Property Taxes: Empirical 
between property taxes and amounts of capital in a jurisdiction, ${ }^{114}$ has been offered in support of the new view.

\section{Summary}

Available evidence does not clearly support the benefit view, suggesting that the new view has some relevance, particularly for the part of the property tax that applies to structures rather than land. The new view does not, however, imply that benefits do not equal taxes. To the extent that taxes and benefits do differ, as one would expect is true to some extent, Part I provides a framework to assess what treatment is appropriate. For concreteness, the present Section generally referred to the treatment implied by the second benchmark: allowing deductions to the extent that taxes paid exceed benefits received and requiring inclusions to the extent that benefits exceed taxes. But it should be kept in mind that such treatment is not advocated here; indeed, the discussion in Section I.C offers reasons for questioning whether any adjustment to taxable inconie is appropriate.

\section{Sales and Income Taxes}

The analysis of state and local sales and income taxes is analogous to that of the property tax, although the relevant empirical assuniptions probably differ. To illustrate, consider a wage tax on workers-which is similar to an inconie tax for the many taxpayers who derive most of their income from wages. ${ }^{115}$ In the new view of the property tax, the central assumption is that capital-which is what is taxed-is perfectly mobile. With the wage tax, assume similarly that labor is fully mobile. ${ }^{116}$

Suppose that in two jurisdictions the wage initially is $\$ 10$ per hour. Jurisdiction $\mathrm{A}$ imposes a wage tax of $\$ 2$ per hour, and

Evidence, 48 Nat'l Tax J. 479, 480-81 (1995) (finding most commercial property tax differences to be borne by capital, not renters).

114 See Wassmer, supra note 9, at 140-52.

$115 \mathrm{Cf}$. McCombs, supra note 27, at 749 (quoted infra note 207) (suggesting the similarity of an income tax and a sales tax given that most taxpayers spend almost all of their income).

116 For evidence that labor is mobile, and, therefore, wages adjust fully for tax differences, see Martin Feldstein \& Marian Vaillant, Can State Taxes Redistribute Income? (National Bureau of Economic Research Working Paper No. 4785, 1994). 
jurisdiction B imposes no wage tax.117 Employers in jurisdiction A would need to raise the wage to $\$ 12$ to avoid losing all their workers to jurisdiction B. Employers in jurisdiction A will have a lower demand for labor when their labor costs are higher. As a result, the wages in A will fall, and some labor will flow to jurisdiction $B$, which will reduce the wage in $B$.

In equilibrium, suppose that the wages are $\$ 11$ and $\$ 9$ in the two jurisdictions. Workers would be indifferent between earning $\$ 11$ while paying $\$ 2$ in tax and earning $\$ 9$ while paying no tax. This assumes, however, that wage earners may deduct the $\$ 2$ tax when they determine their federal taxable income. Otherwise, their federal tax burden would be higher when they earn $\$ 11$ and pay $\$ 2$ in taxes rather than simply earming $\$ 9$. (Their position is analogous to the landlords in Subsection B.2.a.)

Goods and services sold in jurisdiction A will be more expensive, making hiving there less attractive. (The implicit assuinption is that individuals inust purchase goods in the jurisdiction in which they hive, an assumption that is relaxed in a nioment.) But jurisdiction $\mathrm{A}$ is more attractive because the tax generates revenue to finance public services. On average, taxes paid will equal benefits received.118 Those who consume inore goods and services, however, will pay more on account of the tax, just as individuals who rent larger honies paid inore on account of property taxes. Thus, consumers-not wage earners-bear the burden of the tax. If the second benchmark treatment is thought appropriate, consumers should have deductions or inclusions to the extent that the price increases they bear differ from the average borne by community members (assuming the sinple case

${ }^{117}$ At the wage of $\$ 10$, this is a $20 \%$ tax. The example, however, will involve wage adjustments after imposition of the tax; thus, if the stated tax were $20 \%$ rather than $\$ 2$, the amount of tax paid would change as wages change. Although this is indeed how wage, income, and sales taxes operate, exposition is facilitated-by permitting continued use of the same, round numbers-without affecting the logic of the argument by considering a tax that is a fixed amount per unit of work.

118 Various individuals' taxes will differ. Those who work 1,000 hours per year pay $\$ 2,000$ in tax and those who work 2,000 hours pay $\$ 4,000$ in tax, but the wage differences make up for this (just as, with property taxes, landlords who rent larger houses pay more tax but receive more rent). 
in which benefits are equal for everyone). ${ }^{119}$

(Consumers are analogous to the renters in Subsection B.2.b.)

Realistically, one would not expect that labor would be perfectly mobile ${ }^{120}$ and consumption totally immobile. As examined further in Part III, the incidence of the tax will depend on relative degrees of mobility. Whether the tax is borne by consumers or workers significantly affects the argument for deductibility. (If neither consumption nor input suppliers had any necessary connection to the taxing jurisdiction, the tax might collect hittle revenue as employers relocate to jurisdictions without the tax. ${ }^{121}$ )

It should be clear that analysis of a sales tax is similar. If, for example, the tax were borne entirely by consumers in the jurisdiction, the analysis for consumers would be equivalent to that just given for a wage tax borne by consumers. ${ }^{122}$

119 Or a benefit view would be applicable if localities could craft appropriate restrictions, as was the case with the property tax. See George R. Zodrow \& Peter Mieszkowski, The Incidence of the Property Tax: The Benefit View Versus the New View, in Zodrow, supra note 9, at 109, 112.

${ }^{120}$ In particular, many individuals may have their residential choice constrained by the need to live near work combined with their inability to earn the same wage in any jurisdiction. See, e.g., Mieszkowski \& Zodrow, supra note 9, at 1131-32; see also Hamilton, supra note 80 , at 101-02 (discussing constraints on residential location decisions).

121 A distinctive aspect of property taxes is that they may be borne directly or indirectly, through higher rents, by residents - those who receive benefits. (One usually cannot benefit significantly from a jurisdiction's police and fire protection, libraries, parks, and schools if one lives elsewhere.) The only way to receive benefits and pay less taxes is to live in a less expensive residence, as discussed in Section B. It is not surprising, therefore, that most localities rely exclusively on the property tax, with sales and income taxes used by states or, occasionally, by large metropolitan areas. See Henry J. Raimondo, Economics of State and Local Government 171 (1992) (stating that localities using sales taxes are often highly urbanized counties or large cities); id. at 186 (stating that the income tax in most states is imposed exclusively by state government and that local income tax levies are usually by large counties or cities); Nechyba, supra note 73, at 138-39 (arguing that, due to migration, local property taxes will be preferred political strategy even if voters would otherwise prefer mcome taxation).

Another way to focus a tax on residents is to combine a sales tax, a use tax, and a sales tax exemption for out-of-state purchasers. If such a regime is enforced, then the tax is on residents' consumption, wherever it may be. See generally John F. Due \& John L. Mikesell, Sales Taxation: State and Local Structure and Administration ch. 10 (2d ed. 1994) (discussing combined operation of sales and use taxes).

122 There would be no effect on wages in this instance, so the treatment of wage earners does not need to be considered, as it was in the case of a wage tax. 
In all cases, the question remains whether taxes will equal benefits. If individuals have totally free choice among a variety of jurisdictions in which to reside-which is a different question from whether, given their residence, they can work or consume only locally or at great distances-it is likely that jurisdictions will tend to have a hoinogeneous composition, with residents of each jurisdiction receiving benefits equal to the taxes they ultimately bear (perhaps indirectly). To the extent taxes do not equal benefits, the question becomes whether the adjustments of the second benchmark are appropriate. ${ }^{123}$

\section{BUSINESS TAXES AND TAX INCIDENCE}

This Article primarily addresses individuals' payment of state and local taxes, the deductibility of which is controversial. By contrast, it is generally taken for granted that business taxes should be deductible by the businesses that pay them. ${ }^{24}$ After all, business taxes are but one of many business expenses, and business expenses are generally deductible in computing taxable income ${ }^{125}$ because net income rather than gross revenue is agreed to be the appropriate tax base, both to measure accurately economic well-being and to avoid distortions of economic activity.

The deductibility of business taxes raises problems if personal taxes are not to be deductible. One reason is that it can be difficult to determine whether a "business" tax is really a tax on business or rather a disguised tax on individuals. Moreover, the incidence of a business tax may be on the taxing jurisdiction's consumers or workers, who receive the public goods and services financed by the tax. This Part addresses these issues.

\section{A. The Incidence of Business Taxes}

Just as there is a benefit view of the property tax on housing, there is a benefit view of taxes on business. ${ }^{126}$ Businesses receive

${ }^{123}$ See supra Section I.C.

124 See, e.g., Vickrey, supra note 25, at 93.

125 The statement in the text ignores that some business taxes would be capitalized rather than deducted immediately. See, e.g., I.R.C. $\$ \$ 195,263$ (1994). This complication is irrelevant to the principles developed in the text to follow, so it will be ignored.

126 See, e.g., William A. Fischel, Fiscal and Environmental Considerations in the 
benefits from some expenditures in a jurisdiction (such as on fire and police protection, roads, and perliaps access to a more educated work force). ${ }^{127}$ Suppose that the amount of taxes businesses pay, say, through the local property tax, just equals the benefits they receive. ${ }^{128}$ Then the local tax on business is not funding residents' benefits, and the analysis in the rest of this Article would be unaffected. 129

The force-mobility-that leads taxes to equal benefits is similar to that in the case of individuals. Many businesses may be more inobile than individuals, so that the tendency for equalization would be greater. Some businesses, lowever, have limited mobility. Notably, many service businesses (restaurants, barber shops, auto repair) and retailers (grocery stores, pharmacies) need to be close to the customers they serve. ${ }^{130}$ In addition, all businesses need to be close enough to a workforce witl the requisite mix of skills. ${ }^{131}$

Location of Firms in Suburban Communities, in Fiscal Zoning and Land Use Controls 119 (Edwin S. Mills \& Wallace E. Oates eds., 1975); Michelle J. White, Firm Location in a Zoned Metropolitan Area, in Mills \& Oates, supra, at 175; Mieszkowski \& Zodrow, supra note 9, at 1109-10.

${ }^{127}$ See William H. Oakland, How Should Businesses Be Taxed?, in State Taxation of Business: Issues and Policy Options 17, 28 (Thomas F. Pogue ed., 1992).

${ }^{128}$ If businesses impose externalities in the jurisdiction (pollution, congestion), then taxes may exceed direct benefits to this extent. A portion of the tax would pay for public benefits and the remainder would pay for the costs imposed on residents.

129 There is also a capitalization version of the argument: if taxes on property exceed the benefits provided, businesses will not locate in the jurisdiction because of the higher costs; if the land is, say, zoned exclusively for business use, the price of the property will fall until the point at which the reduction in property costs to a prospective business just equals the additional tax that must be paid. (The argument where taxes are less than benefits is analogous.) As before, the argument depends upon binding zoning and other restraints; otherwise, the incidence will be on land, which is immobile. See supra Subsections II.A.2 and note 84, II.B.3 and II.B.4. For empirical evidence that commercial property taxes are borne by property owners rather than being shifted to renters, see William $\mathrm{C}$. Wheaton, The Incidence of Inter-Jurisdictional Differences in Commercial Property Taxes, 37 Nat'l Tax J. 515 (1984). Nevertheless, if business taxes exceed benefits to business, then individual residents' taxes on average will be less than their benefits.

130 When businesses vary in their mobility, the method by which jurisdictions compete to attract business might involve a sort of price discrimination through selective tax concessions. That is, a general tax may apply to all businesses (raising revenue to fund expenditures on residents from immobile businesses), with special concessions made to attract or retain business that is mobile (effectively subjecting such businesses only to a benefits tax).

${ }^{131}$ For a survey of empirical research on the extent to which firm location decisions 
As with taxes on residential property, the analysis of the new view may be relevant. If a business's benefits do not rise in proportion to the value of its property, the business has an incentive to use less property than would be efficient in its operations, and the return to capital will fall. ${ }^{132}$ In equilibrium, the business will charge higher prices; the combination of higher prices and factor price adjustments (for example, lower wages) will be such that the net return to its capital equals that in other jurisdictions. ${ }^{133}$ More of the tax will be reflected in higher prices to the extent product demand is relatively inelastic. ${ }^{134}$ This raises the question why consumers would be willing to pay higher prices. ${ }^{135}$ Individuals would only do so if there were no better alternatives, as when opportunities in low-tax jurisdictions are too far away.

Alternatively, when prices are higher, mdividuals might move their residences to other jurisdictions. In the scenario just described, however, mdividuals may have a reason to stay: if businesses pay taxes for public goods and services that benefit individual residents, residents' individual tax payments will tend to be less than the benefits they receive.

The compensation provided to local residents will generally be imperfect. First, if taxes distort local businesses' use of capital,

are affected by taxes, see Michael Wasylenko, Has the Relationship Changed Between Taxes and Business Location Decisions?, 1994 Proc. Nat'l Tax Ass'n 107 (1995).

132 This result assumes that there are not binding constraints on the business's use of property. See supra note 129.

133 Factor price adjustments need not be downward. Consider wages. The higher price of capital will lead firms to substitute labor for capital, so labor demand will increase for any given level of output. But the level of output will be lower because price must be higher. Lower output will reduce labor demand. Depending on the elasticity of demand for output (which determines the degree to which output falls) and the elasticity of substitution between capital and labor, the net effect could be an increase or decrease in the demand for labor, and thus higher or lower wages. For a more complete discussion of the new view with regard to the effect of a tax on mobile capital on labor and land that is immobile, see Mieszkowski, supra note 87, at 81-90. See also supra Subsection II.B.4 (capitalization of property tax into land prices under new view).

134 Wheaton, supra note 129 , offers empirical evidence that demand is almost perfectly elastic, so that capital bears the burden.

135 Similarly, if wages fall, see supra note 133 , there is the analogous question of why workers would be willing to earn lower wages. (If wages rise, individuals paying higher prices may recover some of the cost through higher wages.) To facilitate exposition, the text will consider only the effect on prices. 
there will be inefficiencies. 136 As a result, the rise in prices will be greater than the gain in tax revenue because the efficiency cost must be coinpensated to induce capital to flow into and remain in the jurisdiction. This factor suggests that moving away would still offer soine benefit. Second, to the extent some consumers or workers reside outside the jurisdiction, some of the costs of the tax on busmess will be exported. Outsiders will effectively finance some public goods and services withm the jurisdiction.

Whatever the precise degree of compensation, in some instances residents will be able to finance soine of their own public sector consumption through business taxes. ${ }^{137}$ What, if any, adjustment in the tax base would best measure ability to pay in this instance? The analysis of different types of taxes in the following Section indicates that the answer depends on whether the incidence is on consumers or workers.

\section{B. Types of Taxes}

\section{Sales Taxes}

Consider a simple sales tax of $5 \% .{ }^{138}$ Its incidence will be allocated between sellers or buyers depending on the relative elasticities of supply and demand, and its mcidence will not depend on whether the tax is nominally imposed on sellers or buyers. The first point is familiar: if delnand is elastic (that is, demand would change significantly in response to a given change in price) and supply is rather inelastic (that is, supply would change little in response to a given change in price), the tax will be borne primarily by sellers. Conversely, if supply is relatively elastic, the tax will be borne primarily by buyers.

Now consider the second point. Suppose that the sales tax is on consumers and that, in equilibrium, they pay $\$ 100$ directly to the seller for a good and $\$ 5$ to the government in tax, for a total of $\$ 105$. If a tax reform required that the tax be paid by sellers

${ }^{136}$ See Oates, supra note 9, at 133-35.

137 Residents also finance public consumption at others' expense when businesses' taxes equal benefits due to the capitalization of taxes into land prices. See supra note 129.

138 The analysis of variants, such as a value-added tax, would be similar. 
rather than buyers, the new equilibrium would have a selling price of $\$ 105$, with sellers forwarding $\$ 5$ to the government. ${ }^{139}$ Putting the argument another way, for any supply and demand curve one might draw, shifting down the demand curve (the effect of a sales tax paid by buyers) and shifting up the supply curve (the effect of a sales tax paid by sellers) by the same amount will result in the same quantity demanded, the same total payment per unit by buyers, and the same net receipt per unit by sellers. Thus, whatever the incidence, it will not depend on whether the sales tax is nominally imposed on businesses or on individuals.

A regime that simply eliminates the personal deduction for state and local taxes without affecting business deductibility would allow businesses a deduction if the tax was nominally imposed on business but not if the tax was nominally imposed on buyers. This apparent discrepancy, however, creates no problem: the result is the same in either case. When the tax is on busmesses, their revenue in the example is $\$ 105$ rather than $\$ 100$, but there is a cost of $\$ 5$ that does not exist when the tax is on buyers. Thus, busimesses' taxable imcome is the same regardless of how the tax is designated. (If and only if the sales tax is included in gross receipts do businesses get an offsetting deduction.) For consumers, they either pay the tax of $\$ 5$ and pay $\$ 100$ for the good or they pay no tax but pay $\$ 105$ for the good. When expenditures on the good and on the tax are both nondeductible, the result is the same.

If, however, the sales tax were deductible to individuals and the tax was deemed to be paid by individuals-the scenario prior to the 1986 tax reform-individuals would show lower taxable income than if a tax with identical mcidence were imposed on busmess and deemed to be a business tax. Alternatively, if one wished to miplement the second benchmark, allowing deductions of $T_{i}-T$, that objective would be undermined if the tax was deemed to be on business.

${ }^{139}$ If the tax were stated as the same percentage of the gross selling price, the $5 \%$ tax on $\$ 105$ would equal $\$ 5.25$, so the equilibrium would differ. But that is because the level of the tax would differ. One can compare either the same nominal rate, $5 \%$, applied to the sale price net of tax, or the lower rate of about $4.76 \%$ applied to the gross-of-tax sale price $(.0476 \times \$ 105 \approx \$ 5.00)$. 


\section{Income and Wage Taxes}

Income taxes are more common than wage taxes, but analysis here will be confined to the latter. Wages are the dominant component of most taxpayers' income and produce most of the revenue from income taxes, ${ }^{140}$ so most of the problem of income taxes is covered by an analysis of wage taxes. ${ }^{141}$

The incidence of wage taxes is determined in a way analogous to that of sales taxes. Here, the sellers (of labor) are workers and the buyers are businesses. A wage tax nominally imposed on business or on workers will have the same incidence. For example, if the wage is $\$ 10$ when workers must pay a wage (or income) tax of $10 \%-\$ 1$-for a net, after-tax wage of $\$ 9$, the equilibrium with a wage tax of $\$ 1$ imposed instead on firms would involve workers receiving a wage of $\$ 9$, with firms paying $\$ 1$ in tax and the workers paying no tax. ${ }^{142}$

With a wage tax, unlike tlie case of a sales tax, federal income taxes paid by individuals in a regime with no personal deduction for state and local taxes do depend on whether the tax is nominally on business or on workers. If the tax is on workers (and not deductible), workers will be subject to income tax on $\$ 10$ for each hour they work. But if the tax is on business, they would be taxed on only $\$ 9$ for each hour they work. Thus, if the tax is nominally on business, workers implicitly receive the benefit of personal deductibility. If the wage tax funds public goods and services that benefit workers and it is believed that personal deductibility is thus inappropriate, this circumvention would be objectionable. ${ }^{143}$ Alternatively, if the limited deductions and

${ }^{140}$ See supra note 115 .

141 This point is stronger for state and local taxes than for the federal income tax because some individuals avoid state income taxes on unearned income by living in low- or no-income-tax jurisdictions different from where they work, but income taxes on wages must still be paid to the higher-tax jurisdiction. This situation raises issues concerning tax exporting that are addressed briefly in Section $\mathrm{C}$.

142 See the discussion in note 139 concerning whether a business tax is imposed on a base that is gross or net of tax. In this instance, the comparison would involve either a $10 \%$ tax on wages gross of tax or an $11.1 \%$ tax on wages net of tax.

143 See William D. Andrews, Basic Federal Income Taxation 481-82 (4th ed. 1991) (suggesting that nondeductibility might lead to a wage tax on employees being replaced by a tax on employers for the payment of wages). The problem is reminiscent of the employer's attempt in Old Colony Trust Co. v. Commissioner, 279 U.S. 716 (1929). Whether deemed employee tax payments or wages, the company would 
inclusions of the second benchmark were deemed appropriate, full de facto deductibility would nonetheless be too generous.

To complete the analysis, note that businesses are in the same position either way. If the tax is nominally on workers, the business deducts wages of $\$ 10$ and nothing for the wage tax. If the tax is on the business, it deducts wages of $\$ 9$ and tax payments of $\$ 1$. To implement de facto nondeductibility by individuals, one could include the business tax payments in taxable wages or, as a surrogate, deny businesses any deduction for wage taxes. ${ }^{144}$

\section{The Incidence of Business Taxes Revisited}

First, consider a property tax. ${ }^{145}$ In Section A, it was observed that if capital is perfectly mobile-that is, if businesses can adjust the amount of property they use-a tax on business property may be borne by consumers through higher prices. To the extent the incidence is on consumer-residents, they purchase more public goods by paying more for private goods. Because private consumption is not deductible, the result with regard to measurement of residents' well-being is similar to the situation where they pay for public goods through personal taxes (in this case, sales taxes) that are not deductible. That the business deducts the property tax that funds residents' public benefits does not alter this result as long as residents indirectly bear the tax through higher prices. (This is analogous to the case in which landlords deduct the property tax, but rents are higher to reflect the public services purchased with the tax revenue. As in that case, if one wished to apply the second benchmark rather than a regime of no deductibility, it would be necessary to impute the business tax to consumers, so that those who purchase

receive a deduction. The employer's attempt to characterize the payment as its own (and not on behalf of the employee) involved the desire to avoid the need for the employee to pay imcome tax on the gross rather than the net wage.

144 If employers are in the same tax bracket as their workers, the effect in equilibrium, including federal tax payments, would be as if the tax were on workers and nondeductible to them. Such a surrogate arrangement could not, however, be easily used to implement the sorts of deductions and inclusions required under the second benchmark when the taxes individuals implicitly bear do not equal the benefits they receive.

${ }^{145}$ A corporate income tax, as imposed by many states, is similar to a property tax: if capital is mobile, it will not be borne by capital and will tend to be shifted to residents-workers, consumers, or owners of local land. 
more would have a greater $\mathrm{T}_{\mathrm{i}}$ and thus a greater deduction determined by $T_{i}-T$.)

It is also possible that the incidence would be on worker-residents, ${ }^{146}$ in which case the analysis in Subsection 2 indicates that they receive a de facto deduction. That businesses deduct the tax leads to a proper measurement of business income. Workers bear the tax through lower wages. Because wages are taxable, the reduction in wages that finances residents' public services reduces taxable income. The situation is as if the services were financed by a wage tax on workers that was deductible. Therefore, business property taxes, to the extent they provide residents with benefits that residents implicitly purchase through lower wages, entail implicit personal deductibility.

The same argument apphes to sales or other taxes if the incidence is on sellers rather than consumers and sellers shift the tax to worker-residents. ${ }^{147}$ Begin with a sales tax. Assume that before the imposition of a sales tax the price of a good is $\$ 100$; after imposition of a $5 \%$ sales tax, the price falls to $\$ 95.148$. This is the extreme case im which the tax is borne entirely by business.

Suppose that businesses do not shift this tax but mstead bear it directly. If the tax finances consumer-residents' public services, then consumer-residents receive the benefit without paying higher prices and without having their taxable income increased. Using the treatment of the second benchmark, one could say that residents' $T_{i}$ is zero, because they do not really bear the tax even though they nominally pay it, and their T mcludes the business tax receipts to the extent that this tax revenue finances benefits for individuals rather than for businesses. Then $T_{i}-T$ is negative for all residents, requiring an mclusion in income of the difference.

146 See supra note 133.

${ }^{147}$ Similar analysis is offered in Bradford \& the U.S. Treasury Tax Policy Staff, supra note 1 , at 85 , to justify the nondeductibility of sales taxes (personal deductibility would result in a double deduction because businesses have already deducted it before paying input suppliers) even though deductibility of personal income taxes is to be permitted.

${ }^{148}$ As before, see supra note 139 , the discussion in the text assumes that tax bases are defined gross or net of taxes in a matter that makes the use of round numbers correct. Here, the $5 \%$ sales tax would have to be on sales gross of the tax. Alternatively, the rate on the net-of-tax base would be approximately $5.26 \%$. 
Is it plausible, however, that businesses would bear the tax when they do not receive the benefits? The answer is affirmative if capital is immobile, in which case owners of the iminobile capital would bear the tax. But if capital is mobile, the tax would have to be borne not by businesses but by others. In the stated scenario in which the tax does not raise consumer prices, workers would bear the tax through lower wages. This would be like the situation described in Subsection 2 of the wage tax implicitly deducted by workers, in which worker-residents do not pay tax on the portion of wage income that funds publicly provided consumption. Alternatively, if consumer-residents are the beneficiaries, it might seen more plausible-contrary to this example's assumption-that they would bear the tax through higher prices, as discussed in Subsection 1. Then, consumer-residents would benefit froin tax-free public consumption only if the sales tax were deductible.

Finally, reconsider the wage tax. Similar arguments can be used to assess who-workers, businesses, or consuiners-is most likely to bear the tax. Similar arguinents also can help determine the implications for deductibility and the measurement of ability to pay.

\section{Tax Exporting}

Much of the discussion in this Part mvolves situations im which taxes nominally imposed on consumers, businesses, and workers are borne by others, as when a business property tax is borne by consumers and workers. The application of the analysis to concerns about the federal income tax deductibility of state and local taxes focused primarily on the case in which businesses, consumers, and workers all reside in the same jurisdiction. But businesses' customers and employees often reside elsewhere. This is true particularly with regard to local jurisdictions, which may be small. In addition, when busmess involves production rather than distribution, or services that may be received by inail or teleplione, consumers often reside im other jurisdictions. ${ }^{149}$

${ }^{149}$ In addition, workers who perform some tasks are increasingly able to supply their services from a distance, with the aid of computers and advances in telecommuni- 
When a jurisdiction imposes taxes that are borne directly by workers or consumers or are shifted to them, and the workers or consumers reside elsewhere, tax exporting occurs. ${ }^{150}$ Outsiders pay for local public goods and services. As noted in Section A, if those goods and services directly benefit the business, this result is neither surprising nor problematic. Businesses ordinarily pay for inputs to production. Prices and wages are normally influenced by the cost of all inputs. Moreover, the greater the mobility of businesses, the less likely it is that jurisdictions will impose taxes on businesses that exceed the benefits provided to them. If capital is inobile, such taxes must be borne by labor or consumers. If labor can be obtained elsewhere and consumers can be served from a distance, businesses will not be able to pass on the cost of such taxes unless the taxes finance benefits to the businesses.

Nonetheless, there are limits to mobility, particularly in larger jurisdictions. Therefore, some tax exporting is likely to occur..$^{151}$ This raises problems of fiscal federalism aside from the question of deductibility of state and local taxes. ${ }^{152}$ Of greatest relevance for present purposes is that matching taxes paid and benefits received is more complex. Individuals will receive public benefits in excess of the taxes they pay to their jurisdiction to the extent some of their taxes are exported. Similarly, individuals will bear the burden of some taxes inposed elsewhere that finance benefits for others.

cations.

150 See, e.g., Richard Arnott \& Ronald Grieson, Optimal Fiscal Policy for a State or Local Government, 9 J. Urb. Econ. 23, 25-37 (1981); Wildasin, supra note 9, at 124-37.

151 Phares estimates that in $1975-1976$ about $17 \%$ of state and local taxes were exported to nonresidents, half of which involved the sort of exporting discussed in the text and the other half of which arose due to deductibility on the federal income tax. Donald Phares, Who Pays State and Local Taxes ch. 4 (1980); see also Charles E. McLure, Jr., The Interstate Exporting of State and Local Taxes: Estimates for 1962, 20 Nat'l Tax J. 49, 64-65 (1967) (estimating that 20-25\% of state and local taxes collected in 1962 were exported to residents of other states).

152 See, e.g., Roger H. Gordon, An Optimal Taxation Approach to Fiscal Federalism, 98 Q.J. Econ. 567 (1983); Daniel Shaviro, An Economic and Political Look at Federalism in Taxation, 90 Mich. L. Rev. 895 (1992); Robert P. Inman \& Daniel L. Rubinfeld, Designing Tax Policy in Federalist Economies: An Overview, University of California, Berkeley, Program in Law and Economics Working Paper No. 93-8 (1993). 
If exporting is significant, however, it hardly follows that permitting deductibility would render taxable income a better measure of economic well-being. To illustrate, consider an extreme case in which there are only busmess taxes, which are borne entirely by workers through lower wages. Also assume that there is substantial exporting across local jurisdictions, but that all taxes are borne within a state. Suppose further that the effect of exporting is that all state residents pay-directly or implicitly-the same amount of local business taxes. (That is, high-tax localities are net exporters of tax burden and low-tax localities are net importers.) Then, if one accepts the treatment of the second benchmark, the appropriate deduction would be $T_{i}-T$, but the relevant $T_{i}$ would not be the taxes one paid directly to one's jurisdiction. Rather, because taxes are reflected in lower wages (everyone's wages are depressed to the same extent), the taxes individuals pay are already implicitly deducted. Thus individuals would all show an inclusion equal to $T$, the per capita taxes imposed by their local jurisdiction.

If, instead, the taxes were all borne by consumers and exported in a manner like that in the illustration, the relevant $T_{i}$ would be a fraction of individuals' consumption because this is what consumers pay through higher prices on account of local public services. Observe that in both cases the $T_{i}$ would not equal the taxes in residents' local jurisdictions, although, as before, $T$ would equal the benefits received-presumed equal to per capita taxes collected-in residents' local jurisdictions.

\section{REDISTRIBUTION}

A portion of state and local taxation is redistributive, as when welfare programs are funded. More generally, any time that benefits received do not equal taxes paid, the state and local government sector as a whole is redistributive. Indeed, the difference between payments made and benefits received can be taken as the definition of redistribution. With pure benefits taxation, individuals all get what they pay for, as when they purchase privately produced goods and services. More generally, individuals' tax payments can be decomposed into two components: (1) a benefits component that by construction equals the benefits received, and (2) a redistributive component that equals 
any residual - taxes paid minus benefits (which would be negative for those whose benefits exceed their payments). ${ }^{153}$

Part I suggests that arguments for adjusting federal taxable income on account of state and local tax payments depend on there being a difference between taxes paid and benefits received. According to the second benchmark, individuals who pay more get a deduction, and individuals who receive more have an inclusion to account for the difference. The appropriateness of such treatment initially was stipulated and then subjected to scrutiny. ${ }^{154}$ In this Part, the basis for that result will be examined further. Because the argument may depend on the reason redistribution occurs, the discussion here will be divided accordingly. Before exploring redistributive motives, however, it is useful to consider the extent of state and local redistribution that may arise in a federal system.

\section{A. Limits on Local Redistribution ${ }^{155}$}

In a system of totally independent jurisdictions, familiar explanations for redistribution would be applicable: namely, it is beheved appropriate that the rich help the poor because resources are relatively more valuable to the latter or equality is favored as a matter of principle. ${ }^{156}$ In a federal system, it is often suggested that such redistribution be undertaken nationally because the justifications for redistribution apply to all citizens and, as a practical matter, mobility inhibits local redistributive effort (as the rich leave high-tax jurisdictions and the poor enter high-welfare jurisdictions). ${ }^{157}$ Indeed, in the United States and many

\footnotetext{
${ }^{153}$ See supra note 44.
}

${ }^{154}$ See supra Sections I.B and I.C.

155 The reader is reminded that "local" is used as a shorthand for state or local, unless otherwise specified.

156 See sources cited in note 61 .

157 See, e.g., Musgrave \& Musgrave, supra note 9, at 454-55; Oates, supra note 9, at 6-8, 137-40; Helen F. Ladd \& Fred C. Doolittle, Which Level of Government Should Assist the Poor?, 35 Nat'l Tax J. 323 (1982); see also David E. Wildasin, Income Redistribution in a Common Labor Market, 81 Am. Econ. Rev. 757 (1991) (indicating the need, on account of labor mobility, for the central government to subsidize local redistribution to an extent that makes the resulting distribution equivalent to that arising under a uniform national scheme). For evidence on the extent to which local redistribution induces migration, see Paul E. Peterson \& Mark C. Rom, Welfare Magnets: A New Case for a National Standard ch. 3 (1990) (arguing that 
other federations, significant redistribution is undertaken nationally.

Local redistribution requires independent explanation. The magnitude of state and local redistribution may be small, in which case there is little to explain. For example, three-quarters of welfare ${ }^{158}$ is federally funded..$^{159}$ Moreover, some state and local redistribution might be induced by federal matching grants. 160

benefits induce migration and that rising poverty rates induce states to cut benefits); Charles C. Brown \& Wallace E. Oates, Assistance to the Poor in a Federal System, 32 J. Pub. Econ. 307, 321-22 (1987) (discussing empirical evidence on migration of the poor); Dowding et al., supra note 75, at 779-84 (literature survey); Edward M. Gramlich \& Deborah S. Laren, Migration and Income Redistribution Responsibilities, $19 \mathrm{~J}$. Hum. Res. 489 (1984) (offering evidence of migration of the poor in response to welfare benefit differences); Henry W. Herzog, Jr. \& Alan M. Schlottmann, State and Local Tax Deductibility and Metropolitan Migration, 39 Nat'l Tax J. 189 (1986) (examining migration in response to state and local taxes); Lawrence Southwick, Jr., Public Welfare Programs and Recipient Migration, 12 Growth \& Change 22 (1981) (presenting evidence indicating high mobility in response to different welfare benefits); Feldstein \& Vaillant, supra note 116 (arguing that labor mobility induces wage adjustments that nullify any redistributive effect of state and local taxes); Phillip B. Levine \& David J. Zimmerman, An Empirical Analysis of the Welfare Magnet Debate Using the NLSY (National Bureau of Economic Research Working Paper No. 5264, 1995); see also Glenn Cassidy, Dennis Epple \& Thonias Romer, Redistribution by Local Governments in a Monocentric Urban Area, 19 Regional Sci. \& Urb. Econ. 421 (1989) (spatial model with simulations). Some estimates suggest that legal constraints that would require greater local redistribution would induce substantial migration. See Inman \& Rubinfeld, supra note 9, at 1727-32 (enforcing uniform residential property assessments and equal benefits in a central city would cause most of the rich and half of upper-middle income families to exit).

158 Much of the discussion of data on redistribution in this Part focuses on welfare despite the fact that any mismatch of taxes and benefits can be understood as redistribution. Welfare is the most significant and obviously redistributive component of state and local fiscal activity, and data on welfare is available. For further discussion of the tendency of taxes to equal the value of benefits due to adjustments in tax rules and the allocation of benefits, see supra notes 77, 101, and 102.

159 See Ladd \& Doolittle, supra note 157, at 323-24 (data for 1980); Allen D. Manvel, Fiscal Facts \& Figures, 66 Tax Notes 1063, 1065 (1995) (observing the "overwhelmingly predominant role of the federal government in financing of economically redistributive functions" through direct federal outlays and federal grants-in-aid). The largest component of federal aid to state and local governments, about forty percent, is for welfare. See Musgrave \& Musgrave, supra note 9, at 484; see also Frederic L. Pryor, Public Expenditures in Communist and Capitalist Nations 177 (1968) (in most countries surveyed, finance of welfare programs is more centralized than public sector as a whole, and the federal share is at least eighty-five percent).

160 See, e.g., Robert A. Moffitt, The Effects of Grants-in-Aid on State and Local Expenditures: The Case of AFDC, 23 J. Pub. Econ. 279 (1984) (indicating that grants significantly affect state redistribution expenditures); Laura S. Rubin, The State and 
The discussion in the Sections that follow assesses the plausibility of various explanations for local redistribution. In all cases, mobility constrains how much redistribution is possible.

\section{B. General Redistributive Motives}

In spite of these limitations on subnational redistribution, general redistributive motives-concern for all the nation's poor-might explain state and local redistribution if state and local demands for redistribution exceed the amount of redistribution provided by the national government. But it seems unlikely that such motives do account for significant redistribution. States-more precisely, their citizens-can engage in national redistribution, which tends to be the preferred cliannel for the reasons given previously. As a result, if most states or localities preferred more redistribution, one would expect the national government to provide it rather than each jurisdiction engaging in redistribution independently. If general redistributive impulses were at work, therefore, one would expect to see redistributive activity undertaken by only those jurisdictions with unusually strong preferences for redistribution. ${ }^{161}$ Furthermore, even if redistributive preferences do vary, the free-rider problem suggests that little, if any, supplemental state and local redistribution would arise. ${ }^{162}$ To be sure, some of the cost of national

Local Government Sector: Long-Term Trends and Recent Fiscal Pressures, 78 Fed. Res. Bull. 892, 895-97 (1992) (stating that in the second quarter of $199273 \%$ of state and local transfer payinents to individuals went to Medicaid and 14\% to AFDC, programs with significant federal inatching contributions). Deductibility itself acts as a matching grant.

Pending legislation might significantly change federal involvennent in such redistribution; if this happens, it remains to be seen whether the extent of redistribution will fall significantly and whether state and local redistributive efforts will rise or fall.

${ }^{161}$ For evidence suggesting that redistributive preferences vary among states, see Larry L. Orr, Incoine Transfers as a Public Good: An Application to AFDC, 66 Am. Econ. Rev. 359 (1976).

${ }^{162}$ To elaborate, suppose there were 10 jurisdictions of about equal size and wealth. In a system of compulsory contributions to national redistribution - the federal income tax-they would vote for some particular level of redistribution. Suppose that one jurisdiction favored twice as much redistribution as others, under the assumption that the costs of the redistribution would be borne uniformly, as through an increase in the federal income tax. If that jurisdiction were unilaterally to increase the redistribution it funds, it would bear the entire cost, rather than one-tenth. Thus, it inight engage in no further redistribution. (Its benefit is twice what others perceive but its cost when 
redistribution is externalized, but only a large amount of externalization could explain significant redistribution due to general redistributive motives. ${ }^{163}$

\section{Although both the free-rider problem and constramts imposed} by mobility ${ }^{164}$ suggest that redistribution would be limited, and although Section A questions the extent to which state and local redistribution occurs, perhaps in practice redistribution is significant. It reinains to be considered whether existing redistribution is best explained by general redistributive motives. If it is, one

acting unilaterally is 10 times as high, so it would find further redistribution unattractive; only if its perceived benefit were more than 10 times as high would it act.) Nor could it expect other jurisdictions to follow its lead. Indeed, if it provided more redistribution unilaterally, the majority might vote for less redistribution at the federal level because the total redistribution would otherwise be higher than the preferred level. (That is, the marginal benefit of redistribution would be less because of the single jurisdiction's additional redistributive activity, but the marginal cost would be as great as before.)

The present analysis assumes that redistribution is altruistic in the sense that those who pay higher taxes for redistribution are motivated by the actual benefit to lower-income recipients. By contrast, recent econonic literature has explored "warm-glow" giving, motivated by the act of the giving in itself. The idea is that a wealthy individual may gain not on account of how much the poor benefit overall but on account of a personal involvement in helping. See, e.g., James Andreoni, Impure Altruism and Donations to Public Goods: A Theory of Warm-Glow Giving, 100 Econ. J. 464 (1990). Sucl motives could explain local giving beyond that which is provided by the federal government, assuming higher-income taxpayers feel an additional warm glow from paying additional state and local taxes for redistribution even though they are already paying (often much greater) federal taxes for the same purpose.

163 When a state redistributes more, it may reduce the state's income (by reducing work incentives) which reduces tax payments to the federal government; thus, a portion of the cost of further state redistribution is borne by the nation. See William $R$. Johnson, Income Redistribution in a Federal System, 78 Am. Econ. Rev. 570 (1988); see also McLure, supra note 151, at 53 (arguing that when state and local taxes are shifted backward and reduce factor returns, gross income and thus federal income tax receipts fall). This effect, combined with current deductibility of state and local taxes, indicates tliat the income tax provides a sort of matching grant that serves to increase redistribution, above the amount produced by direct grant progranis. To this one can add the possibility of tax exporting. See supra Section III.C Nonetheless, it seems implausible that most costs of redistribution are thereby externalized. See supra note 151 (tax exporting, including effect of deductibility and, in the McLure study, indirect offset to federal income tax, results in approximately $20 \%$ of taxes exported out of state). Because most of the benefits of redistribution are external, the free-rider problem would dominate. Grants with high matching rates, however, might overcome the free-rider problem sufficiently to produce significant state and local spending on redistribution. See supra note 160 .

164 See Wildasin, supra note 157 (stating that, witl sufficient labor mobility, the optimal result is uniform redistribution supported by the central government, despite different local distributive preferences). 
should observe jurisdictions giving their funds to the neediest individuals, even if they live in otlier jurisdictions. But it is not the case, for example, that New York State provides welfare benefits to poor residents of Mississippi. While administrative concerns provide some explanation, ${ }^{165}$ it seems doubtful that they are sufficient to explain redistribution patterns, particularly given the substantial disparity in the needs of the poor across jurisdictions. This suggests that other motives, explored in Sections C and $\mathrm{D}$, may be more plausible.

Suppose, lowever, that redistribution lias more general (national) motivations. Those paying higher state and local taxes would provide an external benefit to the local poor and to all the nation's residents. ${ }^{166}$ But a benefit would also accrue to themselves. Indeed, without sucl a benefit, individuals would not be motivated to undertake the expenditures. Therefore, the well-being of those paying sucl taxes arguably is not reduced on account of the redistributive benefits to others. ${ }^{167}$

The situation is like that of a collective gift, 168 and, as Henry Simons argued, gifts should not be deducted in determining income and, moreover, they are regarded as income to recipients. ${ }^{169}$ Pursuing the analogy, it would follow that those wlio pay

${ }^{165}$ It would be difficult for the New York welfare department to determine eligibility in Mississippi. But New York could always provide a block grant to Mississippi's welfare department. It may be concerned that Mississippi would then spend less, although a matching formula could be devised. (These are similar problems to those the federal government faces in funding welfare administered by states and localities or that states confront in giving aid to localities.)

${ }^{166}$ Even if their motivation were solely concerned with the local public good character of redistribution, as explored in Section $C$, there is still an external benefit if residents of other jurisdictions care about the nation's poor.

${ }^{167}$ A contrary result may follow if the tax base is derived by measuring expenditures on preclusive consumption, as in Andrews' argument in favor of the charitable contribution deduction. See William D. Andrews, Personal Deductions in an Ideal Income Tax, 86 Harv. L. Rev. 309, 314-15 (1972); William J. Turnier, Evaluating Personal Deductions in an Income Tax-The Ideal, 66 Cornell L. Rev. 262, 273-74 (1981). As suggested throughout and discussed directly in Subsection I.C.1, the argument in the text assumes that some measure of well-being is most relevant in determining taxable income.

168 It also would be instructive to pursue further the analogy to charitable contributions, which should be analyzed in a manner similar to gifts.

${ }^{169}$ See Simons, supra note 21, ch. 6. From the donor's perspective, the argument is that the donor would not have made the gift but for its production of more utility than the alternative of keeping the resources for direct personal consumption. The 
taxes in excess of nonredistributive benefits should have no deduction on this account, whereas those paying taxes less than benefits should include the difference in income. ${ }^{170}$

On the other hand, efficiency considerations may favor provisions that subsidize giving, which would include voluntary redistribution by a local jurisdiction. ${ }^{171}$ If so, one would have to determine whether a deduction for the redistributive component of state and local taxes is the best form of subsidy (a topic pursued

argument that gifts should be viewed as income to donees is more straightforward and less controversial. For further discussion, see infra note 170.

170 Some argue that gifts should be deductible in principle to donors and included in the income of donees, with the current treatment of no deduction and no inclusion justified on administrative grounds. See, e.g., Andrews, supra note 167, at 348-51; Bradford \& the U.S. Treasury Tax Policy Staff, supra note 1, at 33-35. The analogous result is that the treatment of the second benchmark is appropriate in principle, but perhaps as a practical matter state and local taxes and benefits should be ignored. But the practicality problem seems much less serious as applied to adjustments for state and local taxes. To illustrate, providing the treatment of the second benchmark requires only information about taxpayers' state and local tax payments and the average payments in their jurisdiction. (Adjustments to reflect nonuniform benefits and subtleties of tax incidence complicate the story, but might be amenable to simple formulae that could be applied to all taxpayers in a jurisdiction.) By contrast, implementing a rule that gifts are deductible to donors and taxable to recipients would confront the great difficulty of accounting for myriad gifts, raising administrative and enforcement problems of identifying and characterizing countless transfers. (Deductibility of sales taxes raises accounting problems, but mandatory formulae could be applied given the approximate uniformity of sales taxes paid as a function of jurisdiction and income; gifts given and received hardly have such a uniform incidence.)

One might object that treating tax payments that fund redistribution as a form of consumption (and thus part of income) involves circularity because income is the base from which federal income tax payments to finance redistribution are determined. If there were only a federal income tax, this would raise no problem. (It is well-known that one can redefine uniformly both the base and rate structure in an offsetting manner-e.g., all who earn $\$ 100,000$ can be deemed to have $\$ 10,000$ more income and a larger exemption in that amount.) In considering state and local tax payments for redistribution from the federal perspective, it should be observed that, as explored in the text, there will not ordinarily be significant redistribution; to the extent there is, it will arise on account of particular local benefits or atypically strong preferences for redistribution. Both reasons provide a stronger ground for viewing such redistribution as contributing to the well-being of those motivated to make the necessary expenditures. (Of course, this entire line of argument assumes that individuals' benefits from engaging in altruism should, for purposes of analyzing tax obligations, be viewed as similar to their benefits from engaging in any other activity.) If redistribution is coercive, however, Section D suggests that the analysis would differ.

171 Basically, the idea is that gifts increase total utility (that of the donor and donee) by an amount greater than the benefit to the donor (even when the donor is altruistic). See Louis Kaplow, A Note on Subsidizing Gifts, 58 J. Pub. Econ. 469 (1995). 
in Section VI.A). Federal grants already encourage state and local redistribution. ${ }^{172}$ The justification for subsidizing localities rather than increasing national redistribution is unclear. ${ }^{173}$

\section{Redistribution as a Local Public Good}

Redistribution, to some extent, may be a local public good. ${ }^{174}$ In otlier words, residents of a jurisdiction may benefit from redistributing to poorer neighbors independently of any general benefit they receive from such redistribution as citizens of the same country. There are tangible reasons for localized redistributive preferences: the poor, left unaided, may be inore likely to cause crime or otherwise disrupt others' lives or may be less productive workers in local enterprise. In addition, individuals inay feel inore strongly about the well-being of those closer to them; just as individuals are more inclined to help family or friends than strangers, they inay be inore favorably disposed toward and perhaps have inore in common with those who live nearby. 175

What, then, are the implications of locally motivated redistribution for the arguments about deductibility? If wealthier individuals in a local jurisdiction are benefited by paying inore taxes to benefit their poor neiglibors, as the argument assumes, the benefits received by the wealthy are not in fact less than the taxes they pay. As a result, the argument for allowing a deduction for the difference between taxes paid and benefits received on grounds of ability to pay fails: there is no difference. ${ }^{176}$ The

172 See supra note 160 and accompanying text.

173 See, e.g., Oakland, supra note 36 , at 201, 206-07.

174 See Mark V. Pauly, Income Redistribution as a Local Public Good, 2 J. Pub. Econ. 35 (1973). Even in this case, the amount of redistribution will be constrained by mobility. See id. at 47-56; Brown \& Oates, supra note 157 . Operating in the opposite direction is the fact that some of the incentive or evasion cost froin higher local taxes to fund local redistribution is borne by the federal treasury, so in the absence of mobility local governments inight redistribute more than otherwise. See William H. Oakland, Income Redistribution in a Federal System, in Zodrow, supra note 9 , at $131,140-43$.

175 The empirical significance of this phenomenon may be questioned in a more mobile society. Wealthy residents of Chicago suburbs may feel more connection (if any) to wealthy residents of New Jersey suburbs than to poor residents of the city or in rural areas of Illinois. See Ladd \& Doolittle, supra note 157, at 331.

${ }^{176}$ It would nevertheless be true that the poor would receive benefits in excess of 
analogy made in Section B to a collective gift is applicable, although in this instance the benefit to the donor is somewhat more tangible and direct than in the case of general redistributive motives. As in Section B, however, efficiency considerations may justify a subsidy in some form. ${ }^{177}$

\section{Coercive Redistribution}

Another possibility is that redistribution is coercive. That is, individuals who pay higher taxes prefer lower taxes without redistribution, but they do not have the votes to prevent redistribution. Whether and how much redistribution of this sort actually occurs can be answered only through difficult inquiries that are the subject of positive political theory. ${ }^{178}$ For present purposes, it should nonetheless be noted that there are obvious limits to coercive local redistribution. Although the rich may lack sufficient political power to prevent redistribution, it is not clear that the poor (rather than the middle class) have the power to enact it..$^{179}$ Also, recall mobility constraints. ${ }^{180}$ Such constraints will be strongest at the local level in small jurisdictions, which is consistent with the fact that most overtly redistributive nonfederal prograins are funded by states and large cities. ${ }^{181}$

their tax payments, warranting an inclusion under the second benchmark.

${ }^{177}$ Section VI.A considers whether deductibility of state and local taxes (or some variant thereof) is an effective means of subsidy.

178 For an introductory survey of such theories and evidence, see Mueller, supra note 61 , at 448-55. For analysis of a model in which voters choose local redistribution through property taxes despite mobility (to an extent that tends to be greater when there are more renters), see Dennis Epple \& Thomas Romer, Mobility and Redistribution, 99 J. Pol. Econ. 828 (1991).

${ }^{179}$ Some redistribution may be toward the middle class. For example, state-funded higher education may be of relatively little benefit both to the rich, who might send their children to private schools, and to the poor, whose children might not attend college.

180 See supra note 157 . Feldstein \& Vaillant, supra note 116 , provide evidence that mobility causes wage adjustments that offset the redistributive effect of state and local taxes. They conclude that the best explanation for redistributive state and local taxation is fiscal illusion-a failure to appreciate the effects of mobility-on the part of voters, politicians, or both.

181 More than eighty percent of state and local welfare expenditures are state-financed. See Musgrave \& Musgrave, supra note 9, at 478; see also Cassidy et al., supra note 157 (modeling and providing simulation results for redistribution by central cities). If local benefits are approximately equal among citizens, the property tax is redistributive to the extent housing values vary within the jurisdiction. There are 
The standard arguments for deductibility-those discussed in connection with the second benchmark - seem best supported by the assumption that redistribution is coercive. In that event, it is easiest to argue that those who pay higher taxes without receiving direct benefits have a lower level of well-bemg on this account. Nonetheless, even the limited deductions (and inclusions) allowed under the second benchmark may be deemed inappropriate, as discussed in Section I.C.

\section{INTERJURISDICTIONAL SPILLOVERS}

\section{A. Sources}

Some commentators suggest that state and local taxes should be deductible under the federal income tax because the revenue funds activities that generate benefits to other jurisdictions. ${ }^{182}$ Redistribution is one such activity. Another is education; it is suggested that benefit spillovers arise from residents' future mobility. ${ }^{183}$ But as long as educational benefits are in the first imstance embodied in residents' human capital-and if those residents or their parents pay for the benefit-then any positive externalities would be limited to benefits that are not captured by the recipients of education. ${ }^{184}$ Roads and police protection

limits to mobility among jurisdictions within the state because every locality employs a property tax (although rates vary). Perhaps this scheme reflects states forcing localities to redistribute, although (as discussed in note 76 ) it is not clear why a coalition with the political power to produce this result would not favor direct state financing-or at least imposition of a state rather than a local property tax-because such a scheme would not be subject to pressures from intrastate mobility. See also supra note 159 (indicating that redistribution is funded primarily at the federal level).

182 See, e.g., Billman \& Cunningham, supra note 6 , at 1112 . The anti-deductibility position expressed in Treasury $I$ is defended in this regard on the ground that " $[t]$ here is no reason to believe that most expenditures of State and local governments have such strong spillover effects that they would be greatly under-provided in the absence of the deduction for State and local taxes." 1 Treasury I, supra note 6, at 78; see also Treasury II, supra note 6 , at 64.

${ }^{183}$ See, e.g., Burton Weisbrod, External Benefits of Public Education (1964). Even in the absence of mobility, there is an important external benefit generated to the extent education increases future earnings: those who earn more will pay more taxes and receive less welfare. Thus, local education may benefit state and national finances directly. (This argument is related to the labor-leisure distortion caused by taxation. Individuals in choosing their degree of labor effort do not take into account the portion of earnings they must pay in taxes.)

184 See, e.g., Hamilton, supra note 80 , at 95. 
also provide benefits to those who pass through a jurisdiction, ${ }^{185}$ but tolls are charged on many interstate highways (particularly those used to pass through the entire state), taxes (notably, the gasoline tax) fund some of these costs directly, and a significant portion of road costs are funded by higher levels of government. ${ }^{186}$ Finally, it should be noted that not all externalities from local government activity are positive; for example, having more roads may increase pollution.

In sum, the extent of positive uncoinpensated spillovers is uncertain. Nonetheless, it will be assumed that some do exist, raising the question of their relevance to deductibihity.

\section{B. Relevance to Deductibility}

Suppose that some local expenditures generate significant positive externalities. The argument for deductibility is like that given for redistributive expenditures: if residents pay taxes but others receive some of the benefits, the difference indicates that abihity to pay (net of consumption) is lower. But in the case of (noncoercive ${ }^{187}$ ) redistribution, it was noted that expenditures are undertaken voluntarily and thus will be made only if the internal

${ }^{185}$ For evidence that spillovers are not significant, see Douglas Holtz-Eakin \& Amy Ellen Schwartz, Spatial Productivity Spillovers from Public Infrastructure: Evidence from State Highways, 2 Int'l Tax \& Pub. Fin. 459 (1995).

${ }^{186}$ The federal share for the interstate highway system is $90 \%$ and for other roads $50 \%$. Richard Tresch, Public Finance 626 (1981). And even ignoring federal aid, the majority of state and local expenditures on highways are financed by states. See Musgrave \& Musgrave, supra note 9, at 478.

${ }^{187}$ The analogy to noncoercive redistribution is appropriate. Although some redistribution may be coercive, the coercion is done by local voters who benefit directly. Residents of other jurisdictions do not coerce local residents to build better schools or roads than the local residents would want.

There may be coercion through activities of higher jurisdictions. One form, matching grants, does influence local decisions, but individuals are not usually worse off if they receive bribes that lead them to choose differently. Indeed, they are better off, although to an extent that may be less than the value of grants received because of the condition that funds be spent differently than they would prefer. See also supra Subsection I.B.3 (regarding fiscal equalization). More direct coercion arises if a higher level of government mandates activity that it does not fund. Thus, if a locality would like worse schools but is required by state law to pay for better ones, the difference involves coercion. Nonetheless, the better schools no doubt would provide benefits to residents; their reduction in well-being would be the difference between this benefit and the added cost. In considering both matching grants and mandates, it should be noted that the current Congress is considering substantial reductions in the use of such devices. 
benefits, as perceived by the residents, at least equal the costs. As a result, economic well-being is not lower on account of local taxes in the presence of interjurisdictional spillovers.

The argument with regard to spillovers from, say, highways is more direct than that with regard to redistribution. The suggestion that redistributive expenditures do not warrant deductibility as a matter of income measurement proceeded by analogy to gifts, where the argument in principle against deductibility is controversial. ${ }^{188}$ With other spillovers, by contrast, those who pay for the goods and services benefit directly and tangibly. The situation is analogous to individuals who plant flowers in their front yards: positive externalities are generated for neighbors and passers-by, but no deduction would be appropriate in measuring economic well-being because there is no reason to suppose that people invest inore in their gardens than is warranted by the resulting personal benefits.

Proper mcome ineasurement does not, therefore, provide a strong foundation for even limited deductibility on account of the existence of externalities. ${ }^{189}$ Deductibility might instead be

188 See supra note 170 .

${ }^{189}$ Zelinsky argues that "[i]t is inconsistent to deny deductibility for taxes purchasing highly generalized public services without including in income the value of such services to those who do not finance them." Zelinsky, supra note 6, at 31. But if denying deductibility does give the correct measure of ability to pay, it is not clear how improperly allowing deductibility would somehow offset the error of failing to include benefits to others in their income. Moreover, the failure to include spillover benefits in the income of other jurisdictions' residents may not be serious. If, for example, benefits that spill out of one jurisdiction spill uniformly into others, the appropriate income inclusion would be the same for everyone (except for those in the funding jurisdiction, although they may benefit from spillovers from other jurisdictions), so omitting such a benefit causes little problem for the income tax. (Raising everyone's taxable income the same amount is equivalent to no adjustment and a downward shift in the rate schedule. One might still justify deductibility of a small fraction of state and local taxes as a proxy for the fact that those who pay aboveaverage taxes benefit relatively less due to spillovers from others-assuming that hightax jurisdictions do not tend to be in proximity to each other, enjoying reciprocal spillover benefits.) One might imagine that spillovers from, say, local educational and redistributive expenditures are distributed more uniformly than those from individual's gardens (where most benefits may accrue to immediate neighbors). Finally, when there are direct beneficiaries as with recipients of welfare, it is possible in principle to tax them, and it is commonly argued that the present failure to do so (except in the cases of unemployment insurance, I.R.C. $\$ 85$ (1994), and some social security benefits, I.R.C.\$ 86) involves improper income measurement. See, e.g., Gene Steuerle, Has the Time Come to Tax Welfare and Other Transfer Payments?, 63 Tax Notes 1365 (1994). 
justified on efficiency grounds: just as it may be efficient to subsidize private activities (gardening) that produce positive externalities, ${ }^{190}$ so it may be efficient to encourage local government activity that produces positive externalities. Such activity is already encouraged directly. A significant portion of expenditures on welfare, schools, and roads (particularly those used most heavily for interjurisdictional travel) are provided by higher levels of government. ${ }^{191}$ In addition, more general forms of revenue sharing are einployed (direct grants, municipal bond interest exemption). Higher levels of government frequently use funding mechanisms and inandates, often in combination; ${ }^{192}$ indeed, such activities are designed in significant part to address interjurisdictional spillovers. ${ }^{193}$ The remaining question is whether federal income tax deductibility is a useful supplemental mechanism to address spillovers, a topic considered in the next Part.

(Taxing the poor on welfare benefits is sometimes argued to be counterproductive, but the tax rates remain to be specified-i.e., one who earns $\$ 5000$ and receives $\$ 3000$ in benefits can be taxed the same as one who earns $\$ 8000$ and receives no benefits, with the tax owed being perhaps zero, or a negative amount indicating that further welfare benefits are to be provided.)

190 Coase's analysis emphasizes that privately negotiated solutions may address externalities. See Ronald H. Coase, The Problem of Social Cost, 3 J. L. \& Econ. 1 (1960). With large numbers of jurisdictions-in the tens of thousands, see Musgrave \& Musgrave, supra note 9, at 477-this seems unlikely. Indeed, higher levels of government in a federal system can be understood in significant part as organizations that serve just this purpose of concluding agreements among local jurisdictions to address externalities.

191 In 1985, the state share of state and local expenditures from their own resources (i.e., ignoring grants from the federal government) for the average state was $82 \%$ for welfare, $53 \%$ for elementary and secondary education, and $63 \%$ for highways. See Musgrave \& Musgrave, supra note 9 , at 478 . The high federal share for welfare is described in note 159. Moreover, much of the state and local spending may be induced by federal grants. See supra note 160 . Finally, interstate highways are funded in large part directly by the federal government. See supra note 186.

192 See supra note 187.

193 See Oates, supra note 9, ch. 3. For negative externalities-notably, pollution-higher jurisdictions require local jurisdictions to control their behavior. See, e.g., 33 U.S.C. $\S \S 1311-1314$ (1988) (Clean Water Act); 42 U.S.C. $\$ \S 7407-7410$ (1988) (Clean Air Act). 


\section{DEDUCTIBILITY AS A SUBSIDY}

The discussion of redistribution in Part IV and of spillovers more generally in Part V suggests that deductibility may be attractive because state and local government spending might otherwise be lower than would be optimal from the perspective of the nation as a whole. This Part considers whether deductibility is an effective subsidy.

\section{A. Comparison to Direct Subsidies}

Tax expenditure analysis offers a number of reasons why direct subsidies 194 are better than indirect subsidies provided through the tax system. ${ }^{195}$ First, the use of deductibility as a subsidy - that is, assuming deductibility is not otherwise justified-involves mismeasurement of income, which interferes with the distributive objectives of the income tax. Thus, taxpayers with otherwise equal income pay different amounts of federal income tax depending on the mix of public and private goods and services that they consume.

In addition, deductibility of state and local taxes is commonly criticized for its regressivity. The subsidy favors high-incoine individuals because deductions are worth inore the higher one's tax rate, are greater in magnitude for the rich, and are permitted only to itemizers, who tend to be wealthier. ${ }^{196}$ In addition, deductibility also favors jurisdictions populated by high-income individuals (so that schools in wealthy suburbs are subsidized

194 A common form of subsidy in the present context is a matching grant. For theoretical analyses, see Mark Shroder, Approximately Efficient Federal Matching Grants for Subnational Public Assistance, 45 Nat'l Tax J. 155 (1992) (determining matching rates that adjust for the positive externality resulting from welfare migration; the externality arises because increasing benefits reduces the costs of welfare in neighboring jurisdictions, as some of their residents exit to seek the higher benefits), and Thomas J. Nechyba, A Computable General Equilibrium Model of Intergovernmental Aid (National Bureau of Economic Research Working Paper No. 5420, 1996).

195 For a classic exposition of tax expenditure analysis, see Stanley S. Surrey \& Paul R. McDaniel, Tax Expenditures (1985).

${ }^{196}$ This latter effect is questionable because nonitemizers benefit from the standard deduction, the level of which usually exceeds the itemized deductions nonitemizers would have taken if they had chosen to itemize. This suggests that there is an average benefit to nonitemizers, all other things equal, even though there is no marginal benefit. For further comments about itemization, see notes 4 and 199. 
more than in poorer areas). ${ }^{197}$ In principle, however, this argument is insufficient because rate adjustments can restore progressivity. 198 (Indeed, the repeal of sales tax deductibility in the 1986 tax reform and the proposed repeal of all deductibihity was exphicitly accompanied by rate reductions that were greatest for the rich so that the total effect would be distribution-neutral.) The mequity that remains is produced by mcome inismeasurement: individuals who receive high deductions because they hve in high-tax, high-benefit jurisdictions pay less tax than individuals with the same adjusted gross income who live in jurisdictions with lower taxes and benefits.

Second, deductibility is an inefficient subsidy because it does not target activities with significant externalities. ${ }^{199}$ Thus, a town receives equal encouragement to finance welfare programs, fire protection (for which the benefits are almost entirely local), or infrastructure for new industry that will generate pollution that adversely effects neighboring jurisdictions. 200

Third, the use of deductibility rather than a direct subsidy arguably limits pohitical oversight. For example, whenever there is general tax reform involving changes im rates and the standard deduction, the magnitude of the subsidy changes. This requires adjustments im other, more direct grant programs-which are

197 See, e.g., 1 Treasury I, supra note 6 , at 80,2 id. at 64 (noting favoritism to high-income individuals and high-income jurisdictions); Treasury II, supra note 6 , at 62-64 (same); Bartlett, supra note 6, at 1121-22; McLure, supra note 151, at 73-74. As noted in the following Section, deductibility also could increase progressivity because it may encourage states and localities to adopt more progressive taxes than they otherwise would. Of course, Congress can take into account the incidence of state and local taxes in setting federal income tax rates, so it is not clear that overall redistribution will be affected by whether state and local taxes are deductible.

198 See, e.g., Griffith, Personal Deductions, supra note 11, at 360-63.

${ }^{199}$ See, e.g., Treasury II, supra note 6, at 64. In addition, the provision of subsidy through an itemized deduction affects targeting. Ladd suggests that spillovers are probably lower in rich localities with many high-bracket itemizers and higher in poor or mixed-income areas (cities) with few itemizers. See Ladd, supra note 97, at 196.

${ }^{200}$ Moreover, because the inagnitude of the subsidy varies with income rather than the purposes of the subsidy, further misinatches may arise. For example, individuals in high-income suburbs receive the greatest inducement to increase their local government spending, but they may spend a lower fraction of their budget on programs that produce positive spillovers than a low-income jurisdiction. Substituting a credit for a subsidy would tend to reduce the current disparity in the extent of the subsidy but still would not result in a very good fit between the extent of the subsidy and the magnitude of external benefits produced by a jurisdiction's public expenditures. 
under the jurisdiction of different committees from those considering the tax reform. Also, deductibility of state and local taxes, like other tax expenditures, may mvolve reduced accountability because the subsidy is more opaque..$^{201}$

\section{B. Effect of Deductibility on State and Local Spending}

Deductibility affects state and local spending indirectly. The direct beneficiaries of deductibility are taxpayers-itemizers in particular. Because of the deduction, a given level of state and local taxes or a proposed tax increase will effectively cost them less: $\$ 100$ of property tax costs an itemizer in the $30 \%$ bracket only $\$ 70$. As a result, such taxpayers will favor higher taxes (or be less aggressive in demanding lower taxes) than otherwise. The net result is that state and local spending will be greater. Because the effect is the greatest for high-income taxpayers, it is suggested that the resulting state and local taxes will be more progressive than otherwise. ${ }^{202}$

201 State and local governments may favor the subsidy on this account. If state and local representatives' interests were fully aligned with those of their constituents, there would be no reason to question their views, for if all state governors successfully lobby to retain deductibility, their constituents not only receive the benefits but also bear the burden of higher tax rates or reduced programs that are necessary to cover the revenue cost of deductibility. One suspects, however, that a governor or mayor might believe reelection chances are greater without repeal because repeal might bring pressure for tax reductions from high-income voters that may be difficult to implement without raising other taxes or cutting services, both of which may be unpopular alternatives. State and local government officials were strong opponents of the attempt to repeal deductibility as part of the 1986 tax reform. But the revenue savings were to be used entirely to finance reduced tax rates, rather than being channeled into increased grants. Thus, the political events surrounding the 1986 reform do not provide clear evidence as to which form of subsidy state and local officials prefer. (By contrast, opposition to proposals in the 1970s to substitute direct subsidies for the municipal bond interest exemption do suggest a preference for tax-financed subsidies, perhaps because they are less likely to be cut as part of deficit-reduction efforts.)

${ }^{202}$ See, e.g., Vickrey, supra note 25, at 95-96. But see supra note 197 (stating that Congress may set federal income tax rates in light of progressivity of state and local taxes). For empirical evidence, see Howard Chernick, A Model of the Distributional Incidence of State and Local Taxes, 20 Pub. Fin. Q. 572 (1992) (finding that deductibility increases progressivity of state and local tax systems to such an extent that the combined effect of deductibility on federal, state, and local systems is progressive), and Charles E. Scott \& Robert K. Triest, The Relationship Between Federal and State Individual Income Tax Progressivity, 46 Nat'l Tax J. 95 (1993) (showing that states decreased statutory progressivity of their income taxes following 1980 s federal tax changes, but not to the point of avoiding an effective increase in state tax progressi- 
The empirical significance of this effect of deductibility has been questioned. Taxpayers must perceive the tax subsidy. (Because the effect is greatest for high-income itemizers, it seems plausible that the effect will be appreciated by many.) In addition, the taxpayers who benefit from the deduction must influence state and local tax-setting decisions. Itemizers are a minority of taxpayers, so it is possible that there would be no effect, although their number remains large and they include most wealthy taxpayers (who may have disproportionate political influence due to their higher propensity to vote and ability to use their wealth strategically). ${ }^{203}$ Most studies find that deductibility has a significant effect, although the results vary.204

A further complication is that analysis of the effect of deductibility on state and local spending must take into account that deductibility may mcrease revenue raised from deductible taxes but decrease revenue raised from other taxes. That is, the primary effect of different deductibility rules may be to cause substitution among revenue sources rather than to change total expenditures. Recent studies address this issue and provide conflicting results. ${ }^{205}$ The possibility of substitution is particularly important with regard to the 1986 tax reform, which repealed the deductibihity of sales taxes but retained the deductibility of income and property taxes. ${ }^{206}$ Because of the potential

vity).

${ }^{203}$ Doubt is expressed in 1 Treasury I, supra note 6 , at $78-79$, on the ground that only a third of families itemize. With regard to local rather then state taxes, itemizers (usually homeowners with above-average income) probably are concentrated in particular jurisdictions (suburbs) so that the majority of residents in those jurisdictions may face a lower effective local tax rate on account of federal deductibility. See, e.g., Ladd, supra note 97, at 195 (finding that itemizers in Massachusetts account for a majority of voters in over two-thirds of jurisdictions). But see William G. Hamm, Comments, in Federal Budget Policy in the 1980s, supra note 97, at 203, 206-07 (criticizing Ladd's argument that ehminating deductibility would have a significant effect on state and local spending).

${ }^{204}$ Treasury II, supra note 6 , at 65 , cites a National League of Cities study finding that deductibility increases state and local spending by about $2 \%$. Other studies find a greater effect, ranging up to $20 \%$. See Bartlett, supra note 6 , at $1122-23$ (surveying studies); Edward M. Gramlich, The Deductibility of State and Local Taxes, 38 Nat'l Tax J. 447 (1985); Douglas Holtz-Eakin \& Harvey Rosen, Federal Deductibility and Local Property Tax Rates, 27 J. Urb. Econ. 269 (1990) (finding that deductibility increased property tax rates over $20 \%$ in a sample of municipalities).

${ }^{205}$ See sources cited supra note 3.

206 One study predicted that the Tax Reform Act of 1986 will cause a sniall reduc- 


\section{importance of substitution, many commentators favor uniform treatment of state and local taxes paid by individuals. ${ }^{207}$ But, to}

tion in spending, half from reduction in the number of itemizers, some from the reduction in tax rates, and some from repeal of sales tax deductibility, although the effects of the latter will be offset by substitution. Courant \& Rubinfeld, supra note 97 . Thus far, however, it appears that there has been little substitution away from sales taxes. Metcalf's analysis attributes this to a number of possible factors: deductibility was incomplete because sales tax tables underestimated and were not wholly responsive to sales taxes paid, some sales taxes are exported, and sales taxes may affect different income groups than other taxes; moreover, the rate reductions significantly reduced the benefits of the deduction for income and property taxes. Gilbert E. Metcalf, Deductibility and Optimal State and Local Fiscal Policy, 39 Econ. Letters 217 (1992); Gilbert E. Metcalf, Tax Exporting, Federal Deductibility, and State Tax Structure, 12 J. Pol'y Analysis \& Mgmt. 109 (1993); see Robert D. Ebel, Comment on "Tax Exporting, Federal Deductibility, and State Tax Structure," 12 J. Pol'y Analysis \& Mgmt. 127 (1993) (examining Metcalf's analysis); see also Paul N. Courant \& Edward M. Gramlich, The Impact of the Tax Reform Act of 1986 on State and Local Fiscal Behavior, in Do Taxes Matter? The Econonic Effect of Tax Reform 243 (Joel Slemrod ed., 1990) (analyzing the impact of the Tax Reform Act and finding little movement in sales taxes). The explanation of preserving the existing distribution of tax burdens is supported by Robert Inman, The Local Decision to Tax: Evidence from Large U.S. Cities, 19 Reg. Sci. \& Urb. Econ. 455 (1989), although it is unclear why state politics would produce reliance on nondeductible sales taxes rather than an appropriately adjusted deductible income tax. (For example, by raising mcome tax rates uniformly, including on low-income individuals, and creating or increasing preferential treatment of unearned income, the adjustment in the income tax would have nearly the same incidence as the sales tax.) See Scott \& Triest, supra note 202 (indicating that states adjusted progressivity of their income taxes in response to federal tax reforms in the 1980s).

${ }^{207}$ See, e.g., Billman \& Cunnimgham, supra note 6, at 1115; 1 Treasury I, supra note 6, at 80; Treasury II, supra note 6. An earlier Treasury proposal (1977) advocated different treatment of sales and income taxes, see David F. Bradford \& the U.S. Treasury Tax Policy Staff, supra note 1, at 85 , discussed in note 147, and the analysis in Part III indicates more generally that superficially similar treatment of different taxes need not have neutral consequences. Turnier, supra note 167 , at $275-76,281$, 294 , distinguishes sales and income taxes because sales taxes are tied to consumption. But McCombs, supra note 27 , at 749 , aptly observes that “[i]n a world where the average individual taxpayer spends ninety-eight percent of his earnings, there is very little practical difference between an income tax that takes five percent from the taxpayer as he earns it, and a sales tax that takes five percent from the taxpayer as he spends it." He notes that a major difference is that housing purchases and rentals are not covered by the sales tax; the real property tax can be viewed as a substitute.

The analysis in this Article suggests that the issue of substitution is less straightforward than is often suggested. Suppose, for example, that Congress repealed the deduction for property taxes because it believed they were benefits taxes but retained the deduction for sales and income taxes (perhaps in modified form, as suggested by the second benchmark) because it believed they were redistributive. This inay encourage substitution of sales and income taxes for property taxes, reproducing the situation that would exist if property taxes were deductible in the same manner as sales and income taxes. But, as the analysis in Part II emphasizes, the relationship between 
the extent business taxes would reinain deductible under all proposals, substitution remains an issue. ${ }^{208}$

\section{Efficiency of Decisions about State and Local Goods and Services}

Deductibility also may affect the efficiency of state and local provision of public goods and services. First, when taxes are deductible, residents do not bear the full cost of their jurisdiction's public goods and services. As a result, residents will tend to favor greater public provision than otherwise, as discussed in Section B. If provision would otherwise be undistorted, the result might involve excessive provision of some goods and services and inefficient production of others (as when a good more efficiently produced in the private sector is noved to the public sector because purchases will then be deductible).209 But given the existence of benefit spillovers (including external benefits from redistribution), tax exporting, and imperfections of local politics, it is hardly the case that a regime witl no deductibility

taxes and benefits is endogenous. Property taxes may have been nonredistributive benefits taxes because of interjurisdictional mobility. If mobility is great among localities but not between states, the shift to state sales and income taxes to finance local public services may result in a cliange in the relationship between taxes and benefits, so that the substituted tax will not produce the same distribution of tax burdens and benefits as the original property tax. If the new pattern of taxes and benefits is the same as the preexisting pattern for state sales and income taxes, then it may be appropriate to treat the substituted taxes in the same way. The most important qualification to this story arises from the great differences in what is currently financed by state and local taxes. See, e.g., supra notes 181 and 186. As a result, even if the incidence of any increase in sales and income taxes is the same as that of the preexisting sales and income taxes, the incidence of the benefits financed thereby would be different if the increase were used to finance local public goods and services. But see supra notes 77 , 101 , and 102 (incidence of taxes and benefits tends to be endogenous even taking the type of tax as given).

${ }^{208}$ The issue is complicated by the fact that the incidence of business taxes may fall on consumers or workers, as explored in Part III.

${ }^{209}$ The importance of the latter distortion is limited by the ability of localities to contract out services. Thus, one can fund the services with public funds provided by deductible taxes but still rely on competitive private sector production. (There is the caveat that the benefits from untaxed imputed income from the public capital stock might be lost. See Hulten \& Schwab, supra note 20.) Also, the incentive to minimize inefficiency in the operation of government (whether through direct provision or supervision of contractors) is reduced to the extent a portion of the inefficiency cost is borne by the federal treasury rather than the jurisdiction's taxpayers. 
is perfectly efficient. ${ }^{210}$ The direction and magnitude of net existing distortions is, however, unclear. (For example, benefit spillovers result in inefficiently low provision of goods and services; 211 tax exporting leads to excessive provision.) Moreover, for reasons noted previously, ${ }^{212}$ deductibility is a crude instrument for addressing these imperfections even if some subsidization is desirable.

Second, when taxes but not user charges are deductible, goods and services that could be priced efficiently are not, causing excessive use. ${ }^{213}$ If the government sets the level of goods and services available to each individual, as by rationing, the benefits of the price system in allocating resources are still lost.

\section{CONCLUSION}

How, if at all, federal income tax hability should be adjusted to reflect state and local taxes and expenditures should be determined by concerns for proper measurement of taxpayers' wellbeing and considerations of efficiency. Most of this Article focuses on the measurement of well-being. From this perspective, the appropriate rule depends both upon conceptual problems of income measurement and upon empirical questions about the actual incidence of state and local taxes and expenditures.

In the simplest case, in which individuals pay taxes equal to the benefits they receive, no deductibility or other adjustment on account of state and local taxes results in accurate income mea-

${ }^{210}$ For example, Zimmerman estimates the resource misallocation due to excessive state and local spending caused by interstate tax exportation (where exportation caused by federal deductibility is included), but concludes by noting that because of spillovers the effect may be to increase efficiency. Dennis Zimmerman, Resource Misallocation from Interstate Tax Exportation: Estimates of Excess Spending and Welfare Loss in a Median Voter Framework, 36 Nat'l Tax J. 183, 198-99 (1983); see McLure, supra note 151 , at $69-73$. Phares estimates that the combination of tax exporting, importing, and deductibility results in a net subsidy in all but one state. See Phares, supra note 151 , at $72-82$. For a categorization of externalities among jurisdictions, see Gordon, supra note 152 , at 580 .

211 In addition, if localities must rely on property taxes and if capital is mobile, there may be underprovision on account of "tax competition." See, e.g., Mieszkowski \& Zodrow, supra note 9, at 1120-23; David Wildasin, Interjurisdictional Capital Mobility: Fiscal Externality and a Corrective Subsidy, 25 J. Urb. Econ. 193 (1989); John D. Wilson, A Theory of Interregional Tax Competition, 19 J. Urb. Econ. 296 (1986).

212 See supra note 199.

213 See, e.g., 1 Treasury I, supra note 6, at 80-81; Treasury II, supra note 6, at 64 . 
surement. Convergence between individuals' taxes and benefits will tend to be produced by individuals' choices of where to hive and work, the functioning of real estate markets, and pohtical pressures on state and local jurisdictions. Thus, there is likely to be an important element of truth in the benefit view of taxation.

Realistically, however, economic and political forces may allow for substantial divergences between taxes paid and benefits received. This might be viewed as warranting an adjustment in determining federal taxable income. It is emphasized, however, that the most plausible treatment from this perspective is not deductibility. Rather, individuals might be permitted to deduct only the difference between the taxes they pay and the average level of benefits in their jurisdiction (average tax payments providing a proxy for average benefits). ${ }^{214}$ Similar logic, moreover, would require inclusions in income for those whose taxes are less than average benefits. This treatment differs from the current system and most reform proposals, and it avoids many of the most cominon objections both to deductibility 215 and to the current exclusion of the benefits financed by state and local tax payments. Further analysis, however, raises substantial doubts about whether any adjustments for state and local taxes are conceptually appropriate, even when taxes and benefits diverge substantially.

Whatever treatment of state and local taxes is deemed appropriate in principle, additional complications arise due to the coinplex mcidence of many such taxes. Taxes nominally levied on consumers (a sales tax) might be borne by workers, or the converse may be true (taxes on wages-imcome taxes-might be borne by consumers). Business taxes may be shifted to consumers or workers, who inay reside within the jurisdiction or outside of it. These problems not only complicate the arguments for the proper treatment of personal taxes but may also, in principle,

${ }^{214}$ A number of refinements to this statement were developed in Section I.B and elsewhere.

215 For example, within a wealthy suburb where all residents itemize and are in the same tax bracket, there would be no net effect on total federal taxable income in the jurisdiction: one taxpayer's deduction would be offset by another's inclusion. The only effect would be that those who pay more local taxes but do not receive more services would pay less federal income tax than those who pay less local taxes to receive the same services. 
require adjustments to personal taxable income on account of business taxes.

Fimally, this Article considers whether arguments for deductibility are affected by the fact that state and local taxes may fund imcome redistribution or activities that generate positive spillovers to other regions. The discussion casts some doubt on the significance of these effects, questions whether such uses of public expenditures warrant some sort of deduction for purposes of better measuring taxpayers' economic well-being, and suggests that deductibility is unlikely to be among the most efficient forms of subsidy for such purposes.

In the end, familiar arguments for deductibility are unconvincing for a range of reasons, many of which differ from those usually offered to criticize current provisions. The simplest case for ignoring state and local taxes in determining federal taxable income is conceptually sound but depends upon factual assumptions that depart (perliaps substantially) from reality. The desirability of a system without deductibility or one that uses an mtermediate solution of the sort described (but not advocated) herein is contimgent on a number of considerations imcluding: whether the conceptual arguments for some adjustment are found convincing, how various theoretical and empirical uncertainties concerning the incidence of state and local taxes are resolved, and otlier factors (notably, efficiency considerations and the political feasibility of alternatives) not fully explored here. 